\title{
Shear wave reflection seismic yields subsurface dissolution and subrosion patterns: application to the Ghor Al-Haditha sinkhole site, Dead Sea, Jordan
}

\author{
Ulrich Polom $^{1}$, Hussam Alrshdan ${ }^{2}$, Djamil Al-Halbouni ${ }^{3}$, Eoghan P. Holohan ${ }^{4}$, Torsten Dahm ${ }^{3,7}$, Ali Sawarieh ${ }^{2}$, \\ Mohamad Y. Atallah ${ }^{5}$, and Charlotte M. Krawczyk ${ }^{3,6}$ \\ ${ }^{1}$ Section 1, Leibniz Institute for Applied Geophysics (LIAG), Stilleweg 2, 30655 Hanover, Germany \\ ${ }^{2}$ Geological Directorate, Ministry of Energy and Mineral Resources (MEMR), P.O. Box 7 code 11118, Amman, Jordan \\ ${ }^{3}$ Department 2, GFZ German Research Centre for Geosciences, Telegrafenberg, 14473 Potsdam, Germany \\ ${ }^{4}$ UCD School of Earth Sciences, University College Dublin, Dublin 4, Ireland \\ ${ }^{5}$ Yarmouk University 21173, Department of Geological and Environmental Science, Irbid, Jordan \\ ${ }^{6}$ Technische Universität Berlin, Institute of Applied Geosciences, Ernst-Reuter-Platz 1, 10587 Berlin, Germany \\ ${ }^{7}$ University of Potsdam, Institute of Earth and Environmental Sciences, 14476 Potsdam, Germany
}

Correspondence: Ulrich Polom (ulrich.polom@liag-hannover.de)

Received: 8 March 2018 - Discussion started: 25 April 2018

Revised: 26 July 2018 - Accepted: 21 August 2018 - Published: 21 September 2018

\begin{abstract}
Near-surface geophysical imaging of alluvial fan settings is a challenging task but crucial for understating geological processes in such settings. The alluvial fan of Ghor Al-Haditha at the southeast shore of the Dead Sea is strongly affected by localized subsidence and destructive sinkhole collapses, with a significantly increasing sinkhole formation rate since ca. 1983. A similar increase is observed also on the western shore of the Dead Sea, in correlation with an ongoing decline in the Dead Sea level. Since different structural models of the upper $50 \mathrm{~m}$ of the alluvial fan and varying hypothetical sinkhole processes have been suggested for the Ghor Al-Haditha area in the past, this study aimed to clarify the subsurface characteristics responsible for sinkhole development.

For this purpose, high-frequency shear wave reflection vibratory seismic surveys were carried out in the Ghor AlHaditha area along several crossing and parallel profiles with a total length of 1.8 and $2.1 \mathrm{~km}$ in 2013 and 2014, respectively. The sedimentary architecture of the alluvial fan at Ghor Al-Haditha is resolved down to a depth of nearly $200 \mathrm{~m}$ at a high resolution and is calibrated with the stratigraphic profiles of two boreholes located inside the survey area.

The most surprising result of the survey is the absence of evidence of a thick $(>2-10 \mathrm{~m})$ compacted salt layer formerly suggested to lie at ca. 35-40 m depth. Instead, seismic re-
\end{abstract}

flection amplitudes and velocities image with good continuity a complex interlocking of alluvial fan deposits and lacustrine sediments of the Dead Sea between 0 and $200 \mathrm{~m}$ depth. Furthermore, the underground section of areas affected by sinkholes is characterized by highly scattering wave fields and reduced seismic interval velocities. We propose that the Dead Sea mud layers, which comprise distributed inclusions or lenses of evaporitic chloride, sulfate, and carbonate minerals as well as clay silicates, become increasingly exposed to unsaturated water as the sea level declines and are consequently destabilized and mobilized by both dissolution and physical erosion in the subsurface. This new interpretation of the underlying cause of sinkhole development is supported by surface observations in nearby channel systems. Overall, this study shows that shear wave seismic reflection technique is a promising method for enhanced near-surface imaging in such challenging alluvial fan settings.

\section{Introduction}

Since around 1980 until today, thousands of sinkholes have affected specific areas along the Dead Sea shoreline (Yechieli et al., 2006; Shalev et al., 2006; Abelson et al., 2017), appar- 
ently contemporaneous with the rapid decrease in the Dead Sea level (Sawarieh and Alrshdan, 2011). The sinkhole processes continuously disrupt farming areas, houses, industrial sites, and infrastructure and, therefore, hamper the future economic development of the whole region. Geological and geophysical sinkhole studies started already in the 1990s at both the western (e.g. Wachs et al., 2000) and eastern (El-Isa et al., 1995) shorelines of the Dead Sea. An early map of the main sinkhole sites was published by Yechieli et al. (2002). The sinkholes typically appear in clusters on either alluvial fans or mudflats. Arkin and Gilat (2000) defined two different classes of sinkholes: (a) gravel holes on alluvial fans that consist of highly permeable gravel and sand layers including some silt, clay, and evaporites and (b) mud holes on Dead Sea mudflats that consist of very fine marl, silt, clay, and evaporitic minerals like aragonite, gypsum, and halite.

An early hypothesis postulated that clay softening, liquefaction, and mobilization in the subsurface, due to the dilution of former highly salty porewater by freshwater inflows, generates the sinkholes (Arkin and Gilat, 2000). As discussed by Ezersky and Frumkin (2013), two other factors may control the location of the sinkholes at the Dead Sea: (1) the presence of a thick, massive salt layer that is exposed to a dissolution front at its edge and (2) the presence of subsurface faults that control freshwater inflow into, and thus enable dissolution of, a salt layer. Such controls were suggested on the basis of a variety of methodical approaches (e.g. Yechieli et al., 2002; Diabat, 2005; Closson, 2005; Abelson et al., 2006, 2009; Frydman et al., 2008; Closson and Abou Karaki, 2009; Ezersky, 2006; Ezersky and Livne, 2013; Ezersky et al., 2010, 2013c, 2017).

Although many geophysical studies have been carried out at the Ghor Al-Haditha sinkhole site (Fig. 1a) in the past 24 years, the subsurface structure and the subsurface erosion (subrosion) processes are still rather uncertain. Since the year 2000, several authors have proposed that a several metre thick, massive salt layer lies at a top depth of $35-40 \mathrm{~m}$ b.g.s. at the site, underneath the alluvial fan deposits (Taqieddin et al., 2000; Legchenko et al., 2008; Frumkin et al., 2011; Ezersky et al., 2013 a, b, c, 2017; Ezersky and Frumkin, 2013; Ezersky and Livne, 2013). In this shallow salt layer model, chemical erosion (dissolution) of this salt layer by fresh water flow from the eastern mountain range is supposed to generate initial cavities in the subsurface, which subsequently move upwards due to the continuous solution or collapse of material at the cavity top, up to the final collapse of the ground surface. In contrast, Al-Halbouni et al. (2017) presented an alternative conceptual model for Ghor Al-Haditha, based on photogrammetric surveying, historic satellite image analysis, and field observations. They propose both chemical and physical subrosion of weak material, which consists both of mudflat (including evaporite lenses) and alluvial fan sediments.

Our reflection seismic study resolves for the first time the fine structure of subsurface layers with a high resolution at Ghor Al-Haditha and thereby contributes to reappraising the different models suggested above. We further show that shear wave reflection seismics have advantages for studying highly porous, partly saturated alluvial fans with complex compositions, e.g. compared to $\mathrm{P}$-wave reflection and refraction, which is partly controlled by the pore fluids, and multi-channel analysis of surface wave (MASW), which is only valid in a 1-D layer case. A particular methodological question of interest is to what extent shear wave seismics can be used to identify dissolution processes at depth and early stages of collapse sinkholes.

\section{Site of investigation}

Ghor Al-Haditha is a small village at the southeastern end of the Dead Sea in the province Al Karak of the Hashemite Kingdom of Jordan (Fig. 1a and b). It is located within the Dead Sea pull-apart basin close to the outlet of the Wadi Ibn Hammad valley. Sediments transported down the Wadi Ibn Hammad and the neighbouring Wadi Mutayl have formed a connected alluvial sediment plain, which is in contact with the border of the Dead Sea. The alluvial plain (current elevation nearly -360 to $-380 \mathrm{~m}$ ) was formerly located at the bottom of the Dead Sea and has been dry land since an unknown time. It is now mainly used for market gardening and, for the irrigation of the plants, water flowing from Wadi Ibn Hammad and surrounding springs is stored in some manmade pools in the area.

Khalil (1992) published the geological information of the area (geologic map sheet Ar Rabbah at 1:50000 scale). The bedrock underlying the alluvial plain is not exposed, but on structural grounds it probably comprises limestone (some dolomitic or silicified), marl, chalk, and phosporite of the Ajun and Belqa groups of Late Cretaceous (TuronianCampanian) age and possibly also sandstones of the Ram and Kurnub groups of Cambrian and Early Cretaceous ages. The depth to bedrock under the alluvial fan is unknown. West of Ghor Al-Haditha, the Lisan peninsula rises in the Dead Sea and uplifts at a rate of nearly $9 \mathrm{~mm} \mathrm{yr}^{-1}$ by salt diapirism related to an underlying Usdom evaporate formation of PlioPleistocene age (Taquieddin et al., 2000; Fiaschi et al., 2017). The alluvial plain consists of semi-consolidated sands and gravels, interbedded with layers of silt, clay, and marl (ElIsa et al., 1995; Sawarieh et al., 2000), all of which are considered part of the lacustrine Lisan Marl Formation of Late Pleistocene age. This sedimentation mixture was also observed during the survey in shallow outcrops of $1-2 \mathrm{~m}$ depth along new water pipeline constructions in the whole area and at the flanks of up to $20 \mathrm{~m}$ deep young sinkholes. The alluvial plain also comprises younger, unconsolidated alluvial gravels and sands, especially around the modern wadi outlets. Together with the interbedded marl, evaporites, silt, and clay layers exposed in the adjacent mudflat (former Dead Sea bed), these younger semi-poorly consolidated materials 


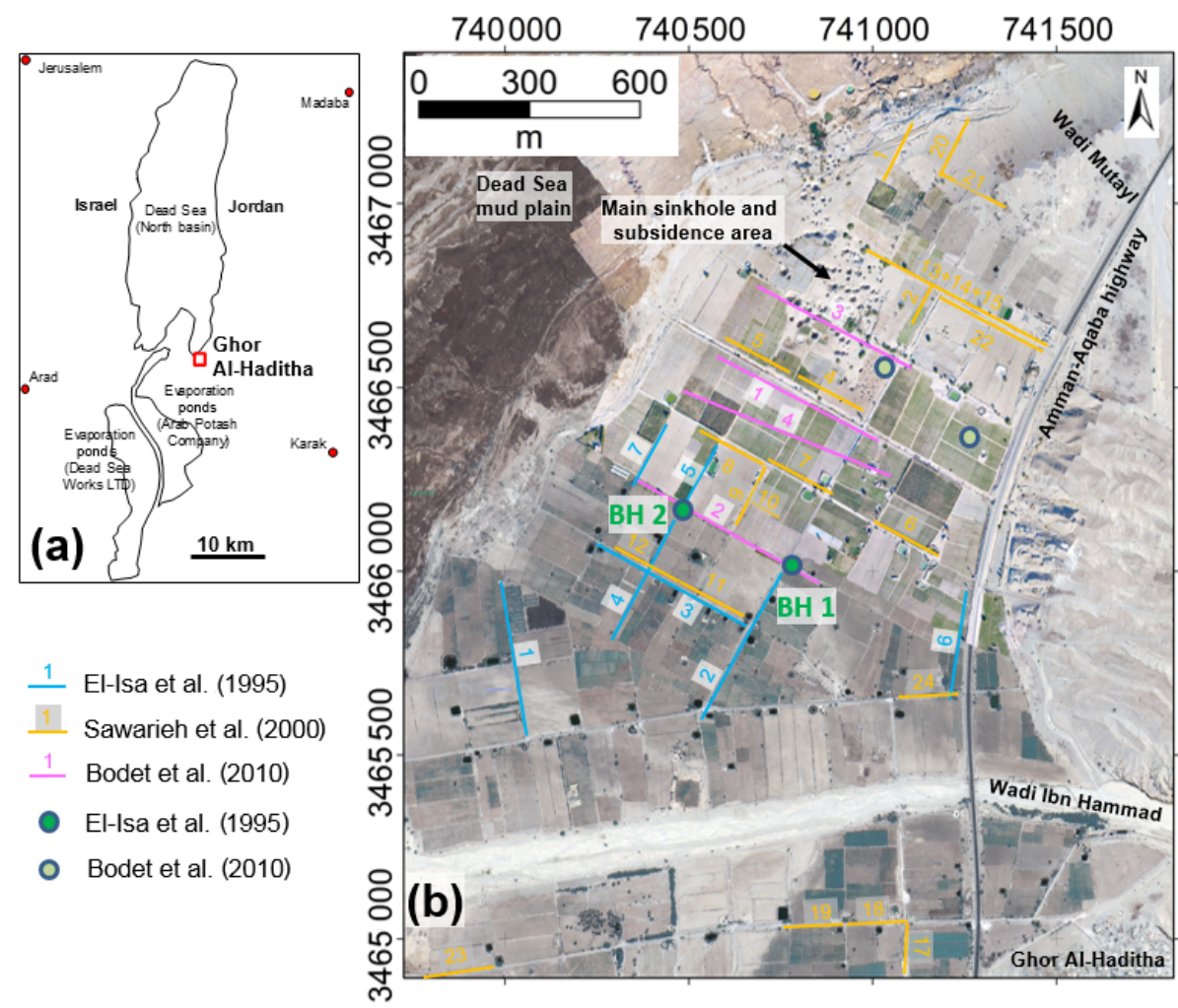

Figure 1. (a) Generalized map of the Dead Sea area. Except for the site Ghor Al-Haditha at the eastern border, which is the focus of this paper, most sinkhole sites are located along the western shoreline of the Dead Sea (see, e.g., Yechieli et al., 2002). (b) Detailed map of the Ghor Al-Haditha sinkhole site and previous refraction seismic (El-Isa et al., 1995; Sawarieh et al., 2000) and MASW (Bodet et al., 2010) profiling. Boreholes BH1 and BH2 are reported in detail by El-Isa et al. (1995); two other boreholes are reported by Bodet et al. (2010) without any further information. Background is a Pleiades satellite image from 2015 combined with an aerial orthophoto mosaic from 2016.

likely correspond to the Ze'elim Formation of Holocene age (Abou Karaki et al., 2016)

\subsection{Borehole information}

Two boreholes (BH1 and $\mathrm{BH} 2$ ) were drilled at the Ghor Al-Haditha investigation site in January-February of 1995 (Fig. 1b), and the drillings and sample analyses were firstly described in a report of El-Isa et al. (1995). Bodet et al. (2010) reported two additional boreholes (Fig. 1b) from 2006 but without further descriptions, and they are not mentioned in other reports and publications. Figure 2 shows the borehole lithology of $\mathrm{BH} 1$ and $\mathrm{BH} 2$ based on a detailed microscopic analysis of cuttings (El-Isa et al., 1995). There, the lithology is described as an alternating sequence of sand and gravel, with a "silt and clay" bed at the bottom down to 51 and $45 \mathrm{~m}$ depth. Nothing is mentioned about a massive salt layer.

Several papers have subsequently presented lithologic cross sections for the Ghor Al-Haditha sinkhole area, in which a thick $(>2-10 \mathrm{~m})$ pure salt layer is postulated to lie at between 30 and $45 \mathrm{~m}$ depth below the surface (e.g. Taqieddin et al., 2000; Frumkin et al., 2011; Ezersky et al., 2013a, b, c,
2017). The above-mentioned boreholes, the reported depths of which vary from one paper to another, are used to support this finding, although no detailed descriptions of the boreholes, no details about the drilling method used, and no lithologic bars are provided. Because the indication of possible massive salt layers is important for comparison with our results, we point out these inconsistencies here.

\subsection{Previous geophysical surveys}

Numerous unpublished studies were carried out in the Ghor Al-Haditha area by the Ministry of Energy and Mineral Resources (MEMR), Jordan (until 2014 the Natural Resources Authority, NRA) subsequent to the first occurrence of the sinkholes (Ali Sawarieh, personal communication, 2013). Early refraction seismic experiments that used standard compression wave (P-wave) techniques were conducted in August-December 1994 by the University of Jordan (ElIsa et al., 1995; blue lines in Fig. 1b), combined with first hydrology and other geophysical studies. The equipment used is only poorly documented; the seismic source was a $7 \mathrm{~kg}$ sledgehammer. Then, hydrology and hydrochemistry work was accompanied by extended seismic refraction (orange 


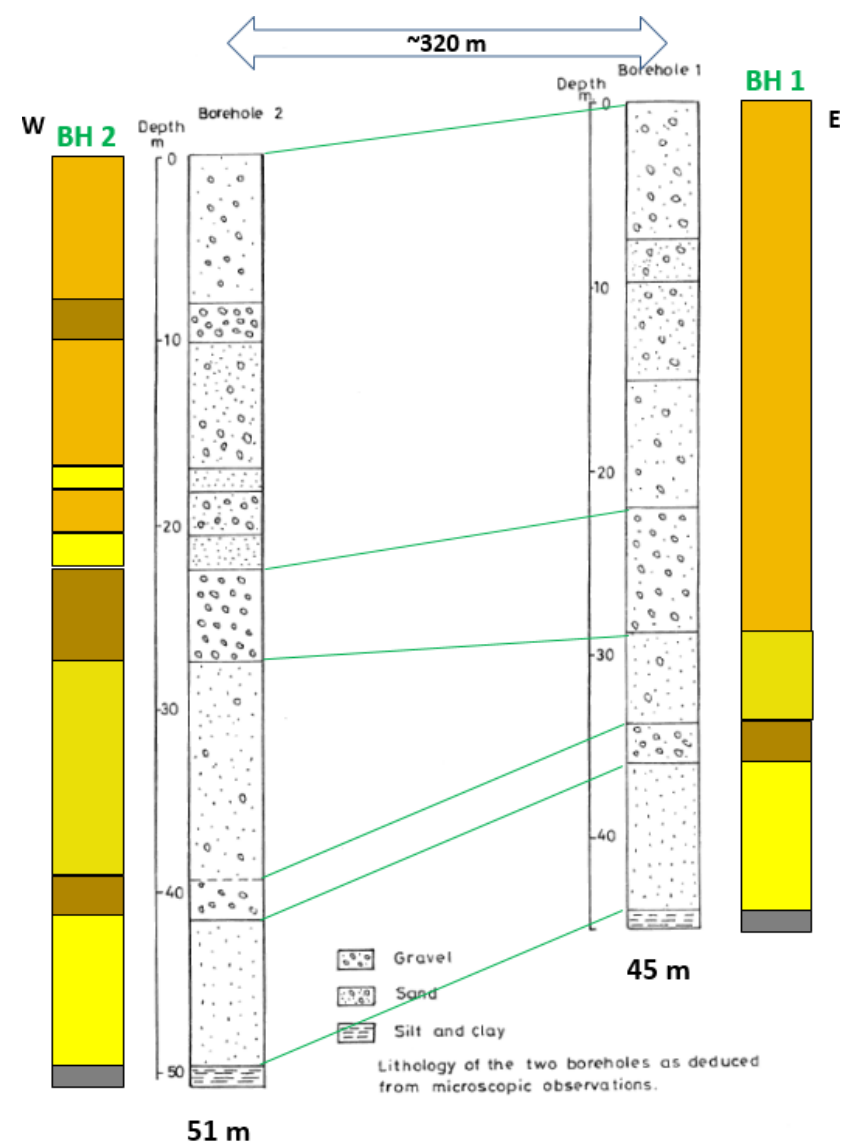

Figure 2. Lithologic columns of the boreholes $\mathrm{BH} 1$ and $\mathrm{BH} 2$ from microscopic analyses, referenced to their surface elevation (black and white columns are the original columns of El-Isa et al., 1995). The coloured, generalized columns are used for the figures of this paper. The main dip tendencies of the units toward the west are visible by the green connecting lines. The annotated borehole depths below the columns follow the text in El-Isa et al. (1995).

lines in Fig. 1b) and ground penetration radar (GPR) surveys in February 1999 (Sawarieh et al., 2000; Abueladas and Al-Zoubi, 2004). Seismic equipment was a $350 \mathrm{~kg}$ weight drop source and a Bison Geopro 8024 24-channel recorder ( $10 \mathrm{~m}$ geophone interval). The refraction seismic surveys indicated that the thickness of the alluvial deposits was more than $70 \mathrm{~m}$, that there was a possible salt intrusion body below (at least $70 \mathrm{~m}$ deep) at one profile location (profile 5 of Sawarieh et al., 2000; Fig. 1b), and that there were also sinkhole-causing cavities at a relatively shallow depth (less than $20 \mathrm{~m}$ ). Except for the one location suspected of having a salt intrusion body, the seismic velocity of the deepest refractor below 40-50 m depth was reported to vary from 2245 to $3300 \mathrm{~ms}^{-1}$ in all profiles, and seismic velocities above this are in general less than $2500 \mathrm{~ms}^{-1}$. Unfortunately, the acquired seismic data of the 1994 and 1999 campaigns are irrecoverable.
Soon after the 1999 surveys, Batayneh et al. (2002) applied GPR to assess the potential of sinkholes of the Ghor AlHaditha area and to determine the location of the filled sinkhole features within relatively dense and more resistive materials. Barjous et al. (2004) carried out a FDEM (frequency domain electromagnetic) survey, supplemented by direct current (DC) resistivity methods (Wenner and dipole-dipole arrays), and conventional geological mapping techniques. During this work a systematic electromagnetic (EM) survey was applied on the Wadi Ibn Hammad alluvial fan.

More recent investigations carried out between 2005 and 2008 used a multi-method approach of transient electromagnetic (TEM) sounding, magnetic resonance sounding (MRS), GPR, and electric resistivity tomography (ERT) (Camerlynck et al., 2012). In 2007, these also included a seismic survey along four profiles targeted at combined reflection, refraction tomography, and MASW data analysis (e.g. Dhemaied, 2007; Bodet et al., 2010; Keydar et al., 2011; Ezersky et al., 2013a, magenta lines in Fig. 1b). For this seismic survey, a Geometrics recorder with a 24-channel geophone $(4.5 \mathrm{~Hz}$ resonant frequency) spread at $5 \mathrm{~m}$ intervals and a sledgehammer source (mass not reported) was utilized. MASW results are published in Bodet et al. (2010) (profile 3 ) and Keydar et al. (2011) (profiles 3 and 4). MASW results and interpretations of profiles 3 and 4 are published in Ezersky et al. (2013b, 2017) and Ezersky and Frumkin (2013). The limit of reliable depth penetration was reported as $60 \mathrm{~m}$ (maximum half-space depth), following the empirical formula $Z_{\max }=0.5 \mathrm{~L}$ of Park et al. (1999) and Rix and Leipski (1991), where $L$ is the total source-receiver spread length of $120 \mathrm{~m}$. Results of profile 3 (magenta line 3 in Fig. 1b) show shear wave velocities of mainly less than $400 \mathrm{~ms}^{-1}$ from the surface to $Z_{\max }$, while profile 4 (magenta line 4 in Fig. 1b) images a high-velocity layer of more than $800 \mathrm{~ms}^{-1}$ from nearly $30 \mathrm{~m}$ depth to $Z_{\max }$, which was interpreted as the shallow salt layer. A reflection seismic analysis result of profile 4 in Ezersky and Frumkin (2013) shows no reflection response of the proposed shallow salt layer, however. Refraction tomography analysis results are reported to be of insufficient resolution (Camerlynck et al., 2012) and are later on shortly mentioned in Ezersky et al. (2017) only.

Three further MEMR geophysical surveys undertaken in 2009 and 2010 with GPR, ERT, and time-domain electromagnetic (TDEM) with NanoTEM technique provide the most recent information about the sinkhole area in Ghor AlHaditha (Alrshdan, 2012). These newer results depict geological and groundwater conditions, the salt-to-freshwater interface, and the limits of safe and vulnerable zones. Alrshdan (2012) also discusses the mechanism of sinkhole formation suggesting that the freshwater inflow acts as the major player, which dissolves cementing evaporite minerals and the fine materials within the alluvial fan, leaving weak alluvial layers and cavities which develop to sinkholes later on.

To shed more light on these different models and to provide an independent database for the detailed mapping of the 


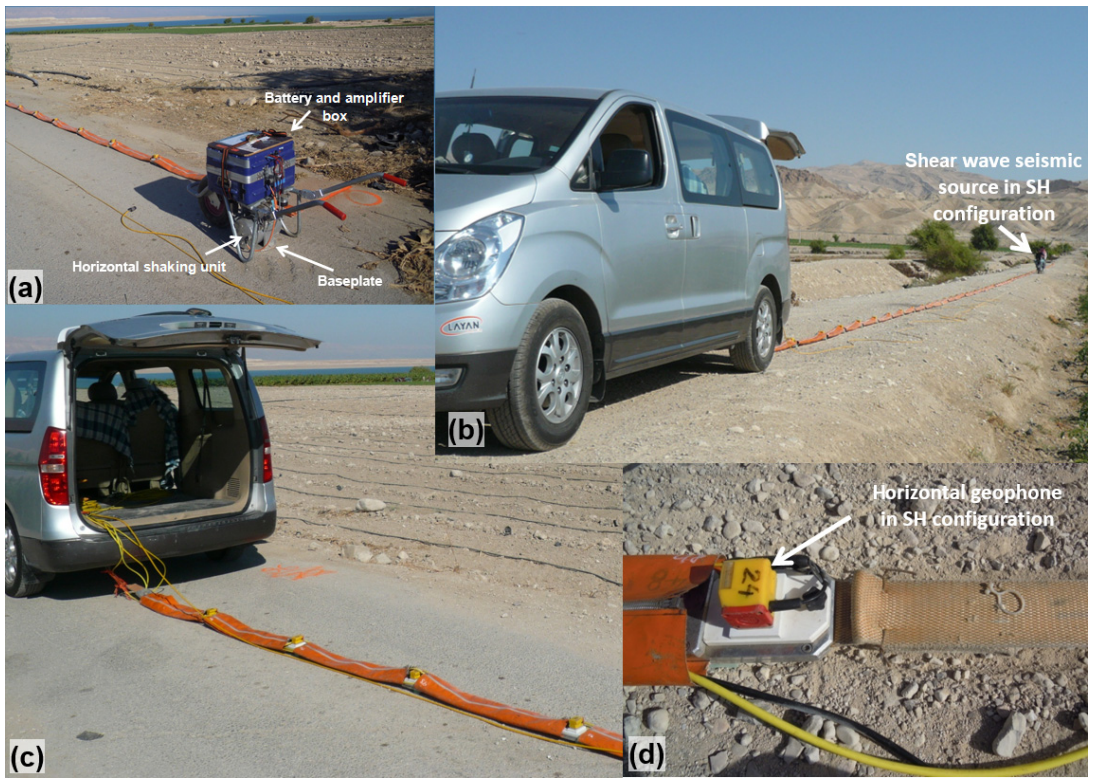

Figure 3. Photos of the shear wave seismic reflection acquisition campaign carried out in October 2013. (a) Wheelbarrow-mounted shear wave source system on asphalt pavement at start location of profile 2. (b) Recording car, towed land streamer and source during operation on profile 3. (c) Land streamer towed by the recording car during acquisition on profile 2. Colour paintings on the road surface were used for location numbering along the profiles. (d) Sledge-mounted horizontal geophone in $\mathrm{SH}$ (particle movement perpendicular to profiling direction) configuration along profile 3 .

postulated salt layer, its morphology, and synclinal structures expected at its top, we started high-resolution shear wave reflection seismic surveying in 2013 at Ghor Al-Haditha. The target depth of the survey was initially focused to the proposed salt layer depth of 35-60 m and, at most, $100 \mathrm{~m}$ depth.

\section{Shear wave reflection seismic equipment and survey}

A shear wave land streamer (Inazaki, 2004; Pugin et al., 2004, 2007, 2013) consisting of 95 transverse horizontal (shear wave horizontally polarized - SH) geophones $(10 \mathrm{~Hz}$ resonance frequency) at $1 \mathrm{~m}$ intervals was used as a receiver unit, connected to a Geode (Geometrics Inc., four units of 24 channels each) recording system. Transverse horizontal (SH) waves were generated by the seismic micro-vibrator source ELVIS (Polom et al., 2011, 2013; Krawczyk et al., 2012). Figure 3 shows the equipment in operation on site. The small size (under $1.5 \mathrm{~m}^{3}$ ) and weight (under $600 \mathrm{~kg}$ ) of the whole equipment enabled air cargo transportation to Jordan.

The source signal (sweep) was set to $20-120 \mathrm{~Hz}(20-80 \mathrm{~Hz}$ during the survey extension in 2014), with a linear frequency modulation on $10 \mathrm{~s}$ duration (Crawford et al., 1960). Data recording was set to $12 \mathrm{~s}$ duration and stored uncorrelatedly to enable the processing of uncorrelated data later on, if required. In the field, vibroseis correlation processing was applied for immediate quality control. After initial tests on site, the source interval was set to $2 \mathrm{~m}$ to increase the statistical redundancy due to challenging, disturbed subsurface condi- tions, noticeable by strong wave field scattering in the recordings. Typically, two records were gained at each source location by alternating the source polarity and stored separately. Only during times of stronger wind disturbances was the number of records per location increased to four. In the 2013 campaign, a total of 2011 records ( $9.34 \mathrm{~Gb}$ data volume) at 898 source locations was gained along $1.92 \mathrm{~km}$ of profile length. In 2014, 2000 records $(9.14 \mathrm{~Gb})$ at 1144 source locations were recorded along $2.1 \mathrm{~km}$ of profile length (see profile locations in Fig. 4).

A variable split-spread source-receiver configuration (Polom et al., 2016) was applied to enable geometry optimization for the detection of dipping structures and to facilitate workarounds due to obstacles in the profile track. To reduce the proportion of Love surface waves during recording, profiles were carried out mostly either on asphalt-paved roads or on dirt roads covered by compacted gravel, so that high shear wave velocities at the surface disable the excitation of Love surface waves. In 2013, geodetic surveying of the profile tracks was performed by using a handheld GPS system. Without differential GPS corrections, the final positioning of the profiles from the 2013 campaign required laborious optimizations by manual corrections based on the known distances along the receiver units. The horizontal accuracy was improved to less than $5 \mathrm{~cm}$ for the profiling and $0.5-1 \mathrm{~m}$ for absolute positioning. Reliable elevation data could not be restored. During the 2014 campaign, the positioning method was improved by using a differential GPS 


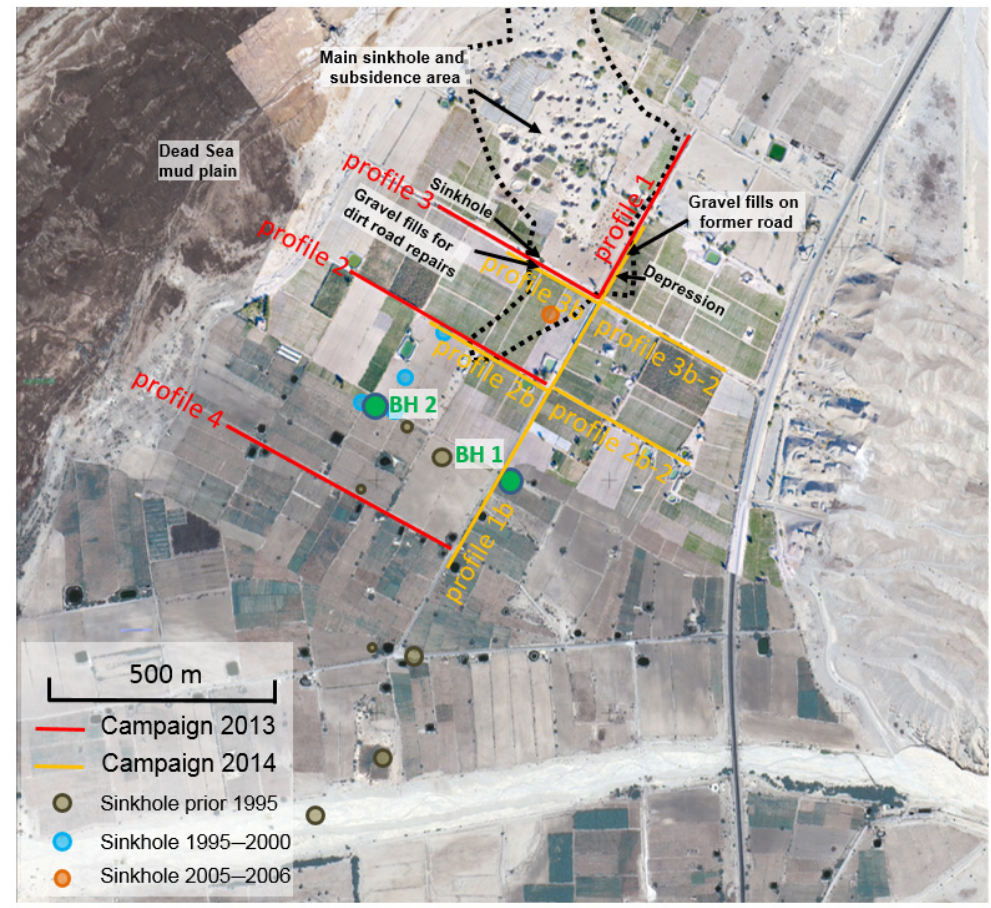

Figure 4. Map of the shear wave reflection seismic profiles acquired in 2013 (red lines) and 2014 (yellow lines). Green circles denote the locations of the boreholes made in 1994 (according to the report of El-Isa et al., 1995). Older refilled sinkholes are denoted by brown circles (after El-Isa et al., 1995), blue circles (after Sawarieh et al., 2000), and the orange circle (after Bodet et al., 2010). The dotted black line marks the main sinkhole and subsidence area after Al-Halbouni et al. (2017).

system, leading to precise elevation data of $10 \mathrm{~cm}$ horizontal and $15 \mathrm{~cm}$ vertical error.

All seismic data recorded were checked and preprocessed in the evening of each recording day by using the VISTA 10.028 (GEDCO Inc., Calgary, CA) seismic data processing software on a notebook computer (DELL Precision M65) for quality-control purposes and a first interpretation. Detailed inspections of correlated raw records showed strong Love wave scattering on profiles 1 and 3 that indicated a low-velocity layer close to the surface, even though the dirt road construction at profile 3 was modified some years ago by gravel infill after heavy damage caused by sinkholes and related subsidence.

Selected record examples along profile $1 \mathrm{~b}$ illustrate the typical range of signal propagation responses at the Ghor AlHaditha site (Fig. 5).

In the northeast sector of the profile, close to the main sinkhole area, a typical scattering of the wave propagation is visible. The wave propagation behaviour is mostly asymmetric regarding the receiver distance to the source position, which indicates heterogeneous subsurface structures. In the middle sector, even though there is an asphalt surface pavement of apparently continuous integrity, Love wave propagation was partly indicated (note the area of Love wave reverberations marked in Fig. 5), probably caused by poor road construction. In the southwest sector, clear reflection events were de- tected already in the single recordings. Along profile $2 \mathrm{~b}-2$ (Fig. 6), selected record examples show a better data quality compared to profile $1 \mathrm{~b}$ : flat first breaks and a range of clear reflection events occur. This is surprising because the road quality along profile $2 b-2$ did not differ from that of the southwest sector of profile 1 , and both roads are of obviously similar age.

\section{Data processing}

Reflection imaging was carried out by following a general processing sequence described by, e.g., Krawczyk et al. (2012) and Polom et al. (2013). The main data processing flow of the first iteration consisted of vibroseis correlation, vertical stacking of records, geometry installation, amplitude scaling, bandpass filter, frequency-wave number (FK) filter, interactive velocity analysis, common midpoint (CMP) stacking, parallel applied frequency-space (FX) deconvolution, and finite-difference (FD) migration. Subsequently, depth conversion was applied by using a mean 1-D velocity function. The background of the data processing applied is reported in Aki and Richards (1980) and Yilmaz (2001).

Since Love wave reverberation patterns are a widely observed disturbance effect in the whole data set (cf. Fig. 5), the elimination of such patterns was one of the main processing steps undertaken to enhance the desired reflection re- 


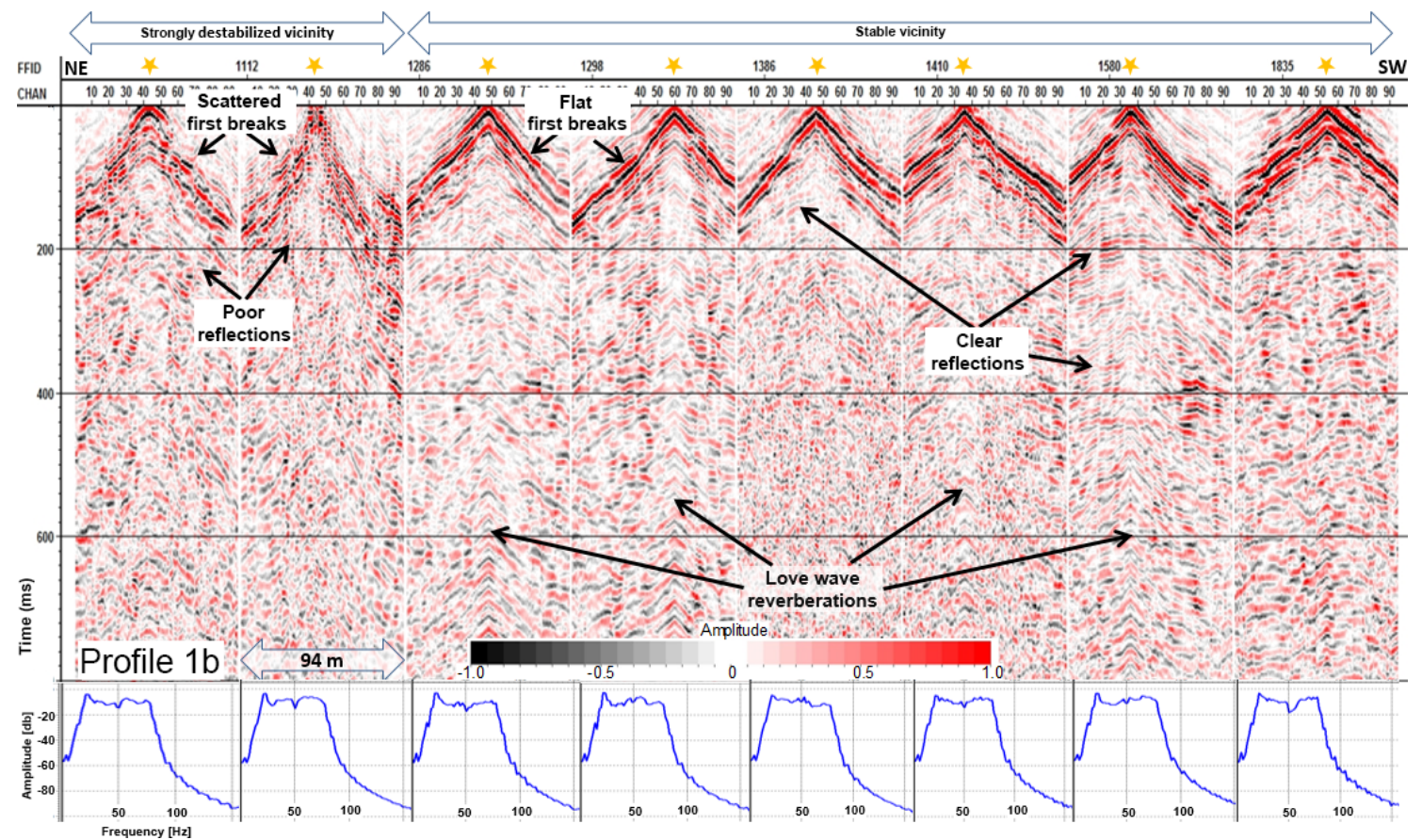

Figure 5. Examples of recorded shot gathers (automatic gain control - AGC of $220 \mathrm{~ms}$ window; amplitude scaling and bandpass filter (18$20-76-82 \mathrm{~Hz}$ ) applied) in the time domain along profile $1 \mathrm{~b}$. The positions of the seismic source are labelled by orange stars. FFID denotes the record number along the profile; CHAN denotes the geophone number along the land streamer unit. Arrows at top denote the condition of the ground surface observed along the profile. In the northeast, close to the sinkhole-affected area, first break and reflection signals are weak due to the strong wave scattering in the subsurface caused by material loosening and cracking. The situation improves towards the southeast, where no sinkholes or other subsidence features were present during profiling and the road surface was in good condition. Below, mean amplitude spectra of the time window 0-400 ms (estimated 0-70 $\mathrm{m}$ depth) for each record are shown.

Table 1. Reflection seismic data processing sequence.

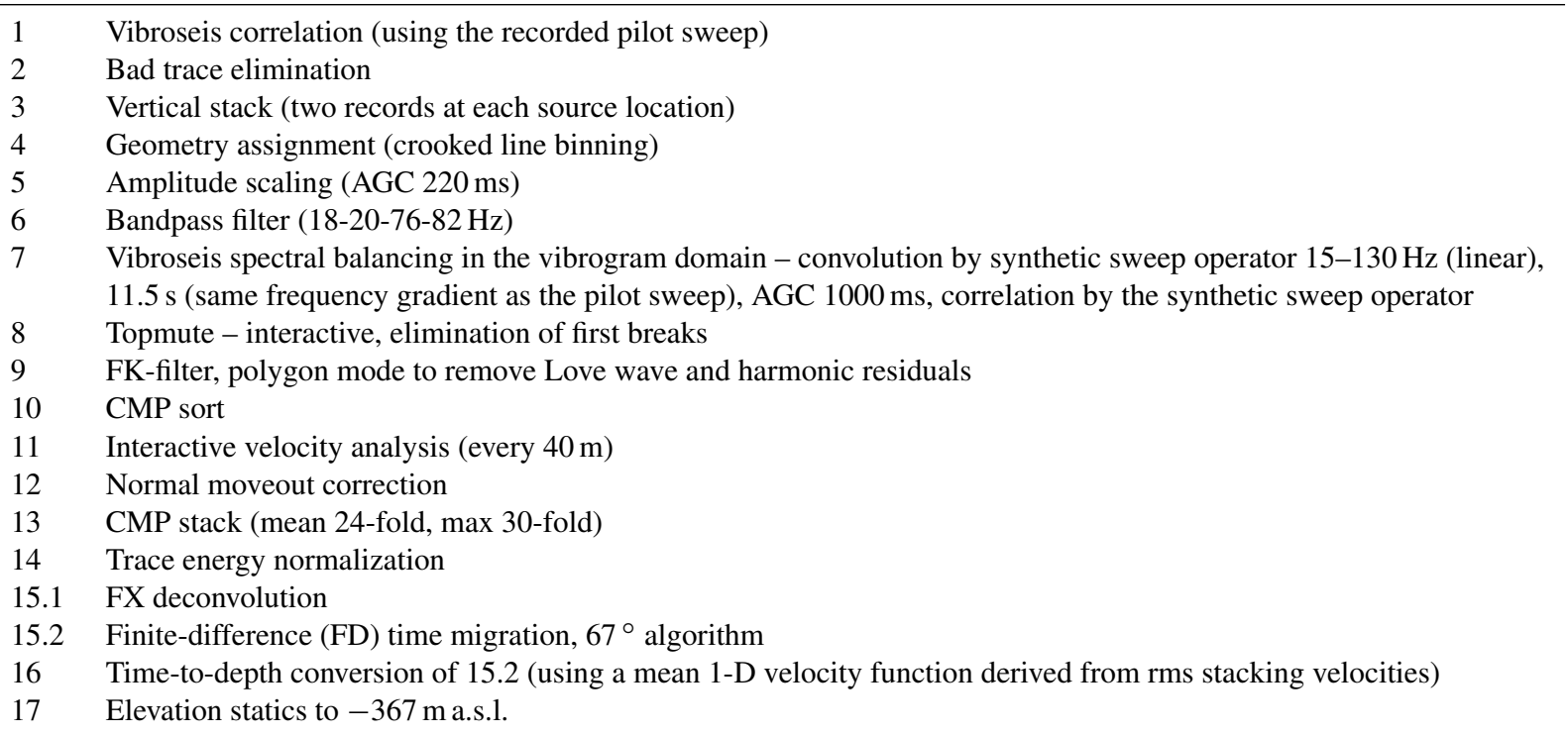

sponse. This required several iterative loops during the main processing sequence to improve the final result. The main data processing was carried out in two iteration sequences mainly by using VISTA 10.028 (GEDCO Inc., Calgary, CA) seismic data processing software. The first sequence was carried out to establish the main database and to extract the main 


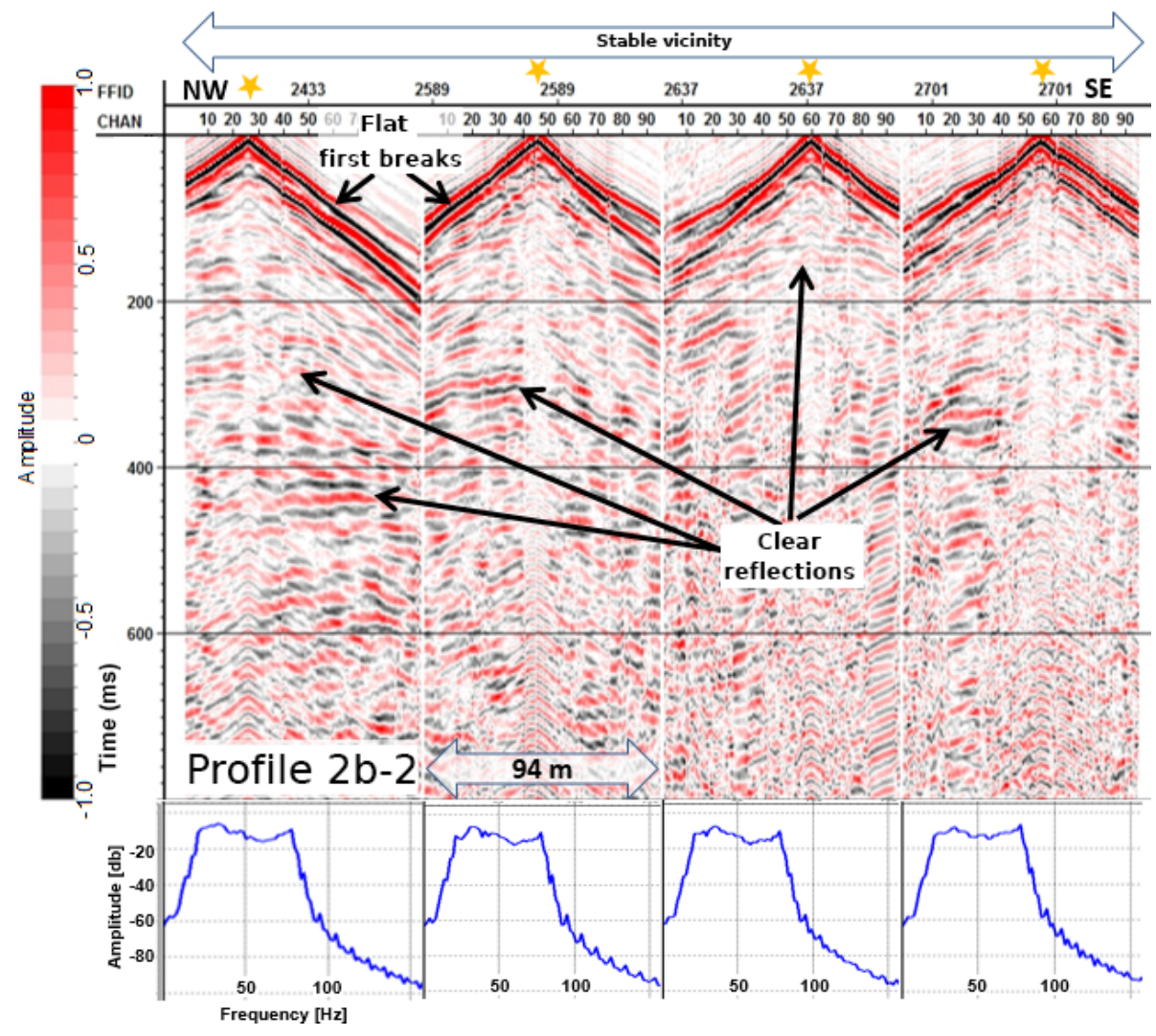

Figure 6. Examples of recorded shot gathers (AGC of $220 \mathrm{~ms}$ window; amplitude scaling and bandpass filter (18-20-78-82 Hz) applied) in the time domain along profile $2 b-2$ (labelling as in Fig. 5). Good signal quality of first breaks and reflections mirrors a rather unaffected signal propagation in the subsurface, which correlates to the sinkhole-unaffected vicinity at the surface. Reflection signals up to $400 \mathrm{~ms}$ in time represent layer responses from $70 \mathrm{~m}$ depth (applying a $350 \mathrm{~ms}^{-1}$ shear wave propagation velocity). Below, mean amplitude spectra of the time window $0-400 \mathrm{~ms}$ for each record are shown.

structures in the data. In the second iteration sequence, the time section results were used to improve the processing flow in detail towards the specific reduction of imaging artefacts and to stabilize the processing velocities for later use during depth conversion. It included reduction of the harmonic distortions in the near-source area and vibroseis spectral balancing (Pugin et al., 2009) in a vibrogram transformation domain (Polom, 1997). Furthermore, the results of the velocity analysis were improved. To derive final depth sections, a mean 1-D rms velocity-time function (shown in Fig. 8) for all profiles was derived from the reflection seismic data set and applied to all profiles. Due to the lack of any reference velocity-depth function, e.g. from vertical seismic profiling (VSP) logging, the 1-D solution was chosen as a first depth approximation to prevent the projection of lateral velocity irregularities (e.g. due to irregular wave ray paths close to sinkhole-affected areas) onto the depth sections, which would result in structure imaging distortions. The detailed processing sequence is listed in Table 1.

Because of these general improvements, some structures in the near-surface down to $50 \mathrm{~m}$ became weaker than in the first iteration. This is a compromise result of combining shal- low velocity results affected by wave propagation along irregular, non-straight ray paths (due to the disturbed shallow subsurface structure) with more regular straight ray path responses from deeper levels (later travel times).

Figure 7 shows a comparison of processed shot gathers of profile 2 in an area of good subsurface reflectivity (profiling distance $325 \mathrm{~m}$ in Fig. 9) after step 5 (Fig. 7a) and after step 9 (Fig. 7b) of the processing sequence in Table 1. Ana$\log$ to the timescale on the left vertical axis, a depth scale is added on the right axis based on a mean shear wave velocity of $350 \mathrm{~m} \mathrm{~s}^{-1}$ to visualize the raw time-to-depth relationship. The record set shows continuous and partly strong reflector elements which are partly covered in Fig. 7a by harmonic distortions (so-called herring bone or chevron pattern) propagating with Love wave velocity of nearly $200 \mathrm{~m} \mathrm{~s}^{-1}$ from the source position. After step 9 of the processing sequence, this covering pattern is removed from the data, showing the reflector structures behind this pattern (Fig. 7b). Such a disturbance pattern typically results from poor road construction where the sub-base layer is not properly done. 


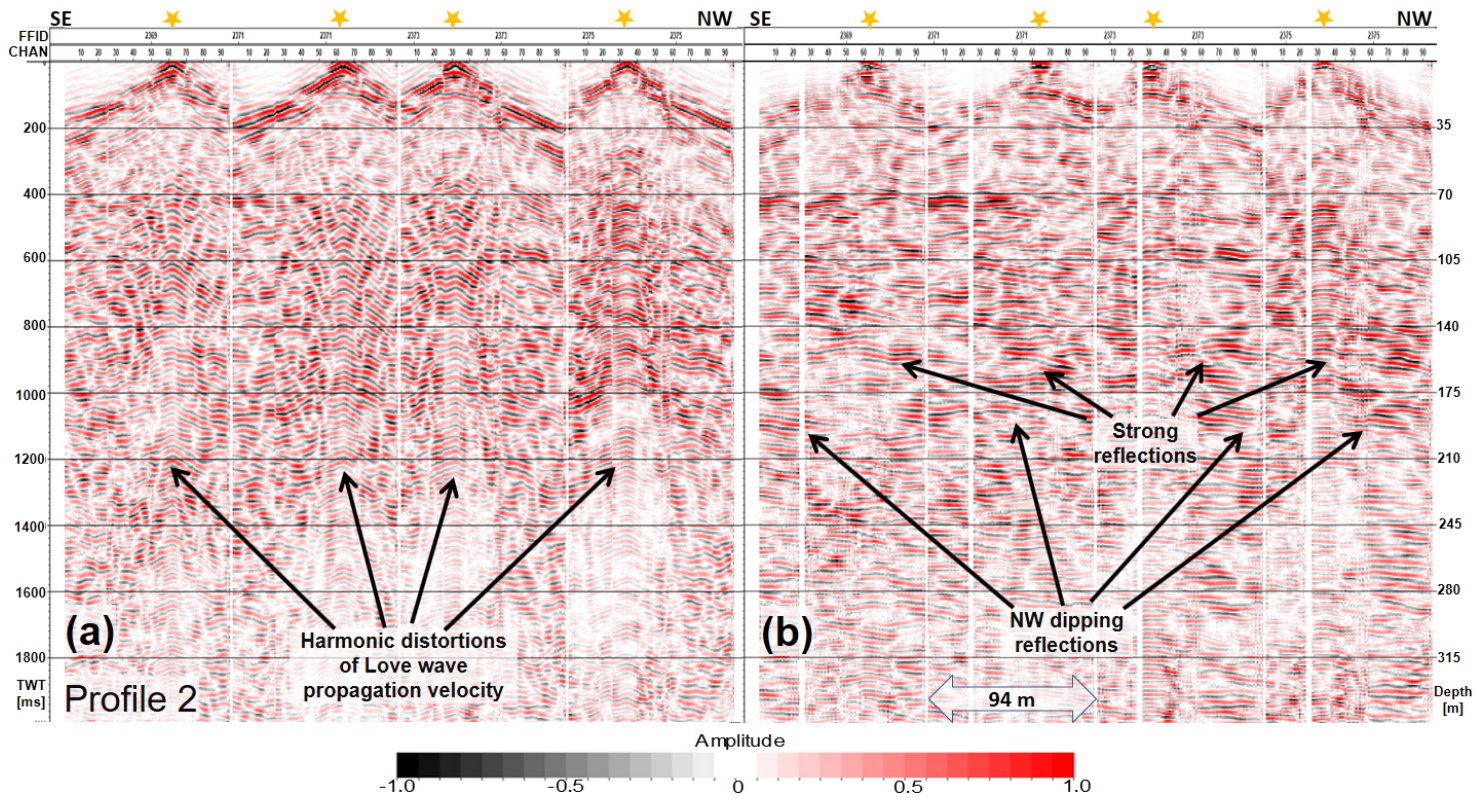

Figure 7. (a) A consecutive set of recorded shot gathers (AGC of $220 \mathrm{~ms}$ window; amplitude scaling and bandpass filter (18-20-76-82 Hz) applied) in the time domain in an area of good reflectivity along profile 2 (labelling as in Fig. 5). Parts of the records are disturbed by harmonic distortions centred on the source position and propagating with Love wave velocity $\left(\sim 200 \mathrm{~m} \mathrm{~s}^{-1}\right)$. In (b) the disturbing pattern is removed, uncovering the reflection events below. For a raw time-to-depth estimation, a depth scale is added on the right based on a mean velocity of $350 \mathrm{~m} \mathrm{~s}^{-1}$ for body shear waves. In (b) Topmute (step 8 in Table 1) is also applied.

\section{Resulting depth sections and structure correlations}

The main northeast-southwest-trending profile $1 \mathrm{~b}$ has transparent and strongly layered segments between the ground surface and $200 \mathrm{~m}$ depth (Fig. 8).

The depth section of profile $1 \mathrm{~b}$ refers to a reference level of $-367 \mathrm{~m}$ a.s.l., and it includes annotations of joints to the other profiles, remarks about the surrounding area (top), and information on the road construction (bottom). The location of borehole $\mathrm{BH} 1$ which is nearly $10 \mathrm{~m}$ southeast of the profile is projected perpendicularly into the profile and shown with a simplified lithology (see Fig. 2). The mean 1-D velocity function used for time-to-depth conversion is given as interval velocity in depth (Dix, 1955) beside the borehole BH1. It shows estimated shear wave velocities in the range of 250 $450 \mathrm{~ms}^{-1}$ down to depths of about $170 \mathrm{~m}$. Finally, the reflection amplitude responses throughout all seismic sections represent reflection coefficients of nearly 0.1 or less, indicating materials with relatively low contrasts in seismically sensitive material properties (elastic parameters and density) and hence in shear wave seismic velocity.

The main area of sinkhole activity is located immediately northwest of profile 1 (see Fig. 4). This activity has strongly affected the road construction along this part of profile $1 \mathrm{~b}$, northeast of its intersection with profile 3 (Fig. 8). A depression with several fractures is visible here along the road surface (Fig. 4) but without any sinkhole activity up to now. In detail, this part of the road crosses the southeastern limit of a major sinuous depression that runs down to the former Dead Sea shore and that hosts the smaller-scale sinkholes (for details, see Al-Halbouni et al., 2017). Several gravel infills on the former asphalt surface in the past make this part of the road usable. Further along profile $1 b$, to the southwest of its intersection with profile 3 , the road stability continuously increases. The road surface is essentially unaffected by subsidence along the area denoted as stable along the southwest half of the profile $1 \mathrm{~b}$. Within this stable area, from the intersection of profile $1 \mathrm{~b}$ with profile 2 to the borehole $\mathrm{BH} 1$, a continuous reflectivity pattern is visible below $50 \mathrm{~m}$ reference depth (i.e. nearly $45 \mathrm{~m}$ below the ground surface). The top of this pattern nearly correlates with the depth of the silt and clay layer detected $44 \mathrm{~m}$ below the ground surface in borehole BH1. The bottom of the nearly horizontal pattern reaches nearly $100 \mathrm{~m}$ depth below reference level along much of the profile, although southwest of the BH1 location, the pattern extends downward to $230 \mathrm{~m}$ depth within a $V$-shaped structure. Northeast of the intersection of profiles 1 and 2, the pattern becomes weak and disappears northeast of the intersection of profiles 1 and 3. Also southwest of borehole BH1, the horizontal pattern weakens and bowlshaped structures become more dominant. Overall, the pattern widely correlates with the stable part of the road, where no sinkholes have occurred yet. Above this pattern, around the borehole BH1 location, nearly horizontal layers occur which show finer subdivided structures resolved down to metre scale. This finer layered structure also abruptly disappears 


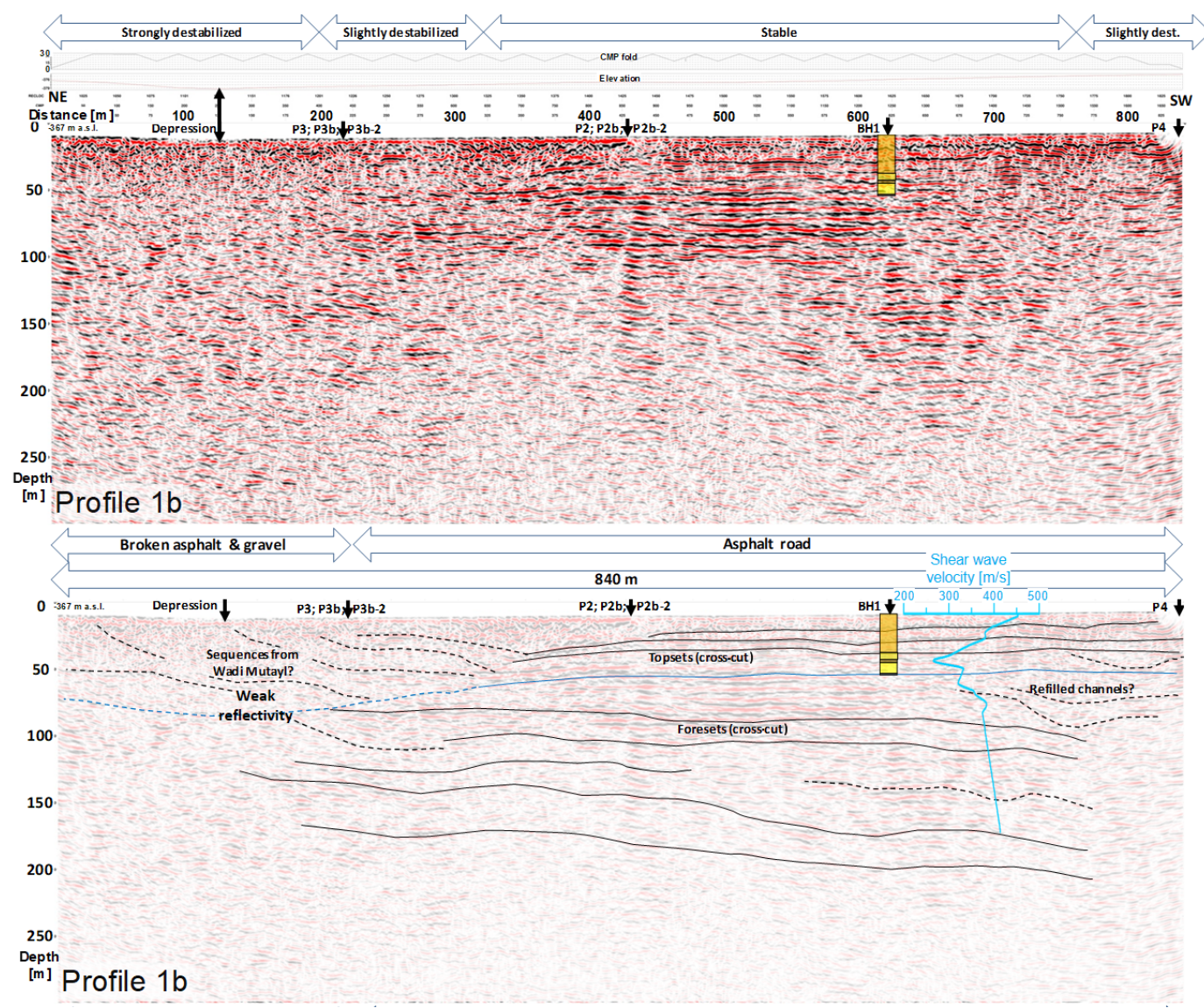

Figure 8. Resulting depth section of profile $1 \mathrm{~b}$ after post stack FD time migration (a) and interpretation of the main structure elements (b). Arrow bars at the top of the upper image denote the surface instability/stability as observed along the profile, while arrow bars below denote the road surface situation along the profile and the profile length. Black arrows at the top indicate joints with the crossing profiles. The lithology of borehole $\mathrm{BH} 1$ is projected from $10 \mathrm{~m}$ distance perpendicularly into the profile. The interpreted top of the silt and clay layer in $\mathrm{BH} 1$ is shown as the blue line along the profile, since it is the first layer detected at depth that is prone to subrosion. Also shown is the 1-D shear wave velocity-depth function derived from seismic data in this area; this function was used for time-to-depth conversion of all profiles.

northeast of the intersection of profiles 1 and 2, i.e. as one approaches the main sinkhole area.

The combined depth sections of profiles 2 and $2 b-2$ are shown in Fig. 9. The profiles were both acquired on an asphalt road. Also shown in Fig. 9 are the simplified lithological bars of boreholes $\mathrm{BH} 1$ and $\mathrm{BH} 2$ as projected perpendicularly into the profile plane from their true locations nearly $200 \mathrm{~m}$ to the southwest (cf. El-Isa et al., 1995). Due to this relatively large projection distance, the lithology bars may not precisely reflect the lithology in the profile plane. The sections show a nearly horizontal layering down to $50 \mathrm{~m}$ depth below the reference level of $-367 \mathrm{~m}$ a.s.l. in the southeast part of the combined profile, which changes laterally to less well organized but mainly northwest-dipping structures in the northwest part of the combined profile.

Below $50 \mathrm{~m}$ depth the main structural dip is towards the northwest and is divided into several dip sequences visible down to nearly $250 \mathrm{~m}$. Along profile 2, between profiling positions 75 and $200 \mathrm{~m}$, there is a slightly more disorganised seismic response above $50 \mathrm{~m}$ depth (i.e. from 30 to $35 \mathrm{~m}$ below the ground surface). This is spatially associated with a local depression and related cracks in the road. At least one sinkhole formed directly adjacent to this part of road prior to 2000 (Sawarieh et al., 2000) and was subsequently filled in. Along profile $2 \mathrm{~b}-2$, at profiling position $125 \mathrm{~m}$, a striking stack of bowl-shaped structures is visible from the surface down to nearly $75 \mathrm{~m}$ depth. Along this part of the profile and for at least $300 \mathrm{~m}$ on either side of it (i.e. towards the northeast and southwest), no sinkhole activity was reported in the past.

The combined depth sections of profiles 3 and $3 b-2$ are shown in Fig. 10. The boreholes $\mathrm{BH} 1$ and $\mathrm{BH} 2$ are not included in the profile plane due to the distance of nearly $420 \mathrm{~m}$ from their true positions further southwest.

Profiles 3 and $3 b-2$ were acquired on a gravel farm track and on a gravel path, respectively, both close to a parallel drainage channel. A $250 \mathrm{~m}$ long segment of the farm track along profile 3 was refilled extensively in the past. The main 


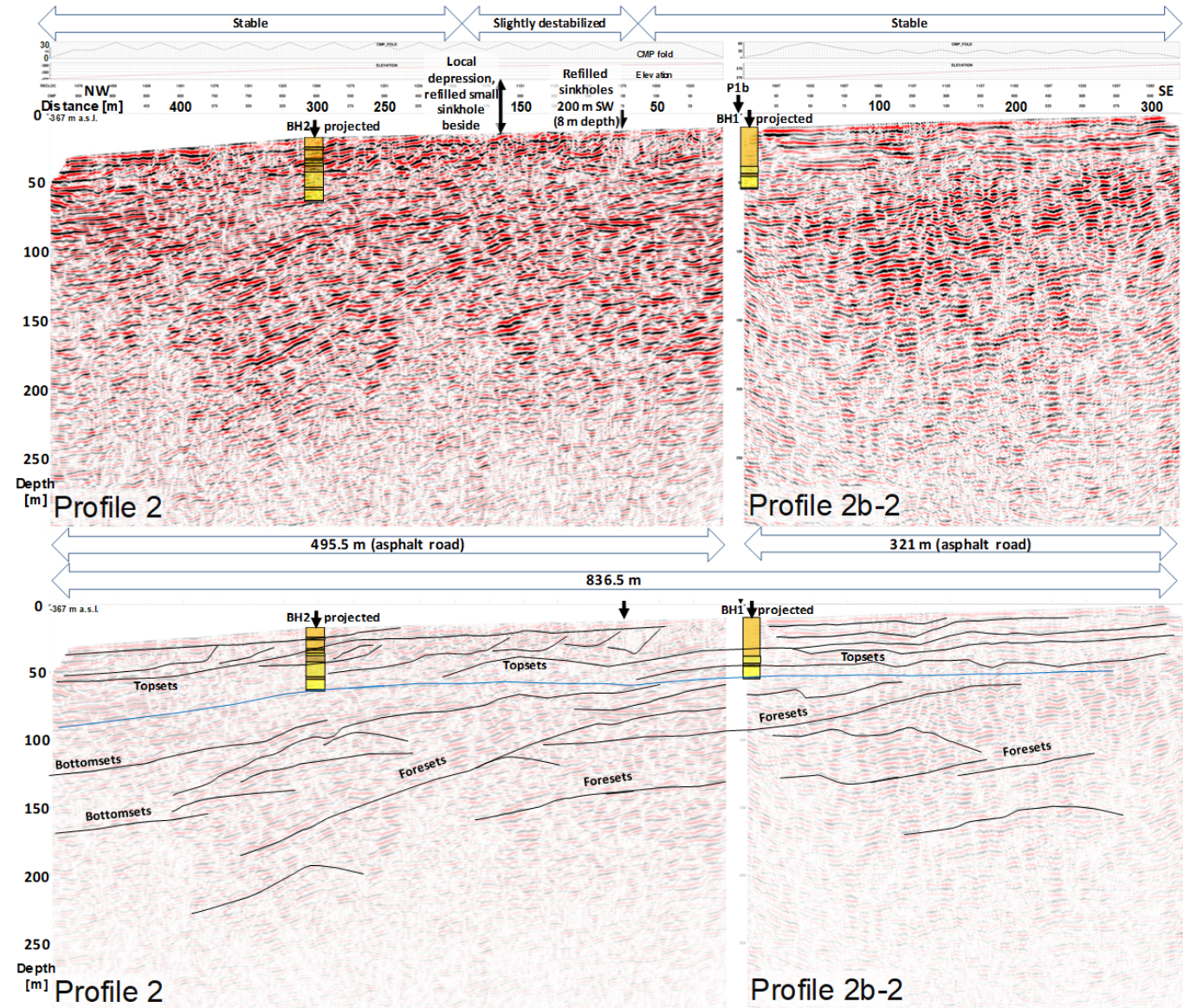

Figure 9. Resulting depth sections of combined profiles 2 and 2b-2 after post-stack FD time migration (a) and interpretation of the main structure elements (b). For annotations, see Fig. 8. Lithology of boreholes BH1 and BH2 is projected perpendicularly into the profile from $200 \mathrm{~m}$ distance and therefore may not show the precise layering signature. Except for the top $40 \mathrm{~m}$, the main characteristics down to $200 \mathrm{~m}$ show stacked sequences of northwest-dipping reflectors, which are interpreted as northwest-prograding alluvial fan sequences. The interpreted top of the silt and clay layer in $\mathrm{BH} 1$ and $\mathrm{BH} 2$ is shown by the blue line.

area of sinkhole activity lies immediately northeast of this refilled section of profile 3 (see Fig. 4), and indeed a recent sinkhole (formed in 2008) was located directly beside the track during data acquisition.

Northeast of profile 3b-2, no sinkhole activity was reported in the past. Due to the different surface conditions, and probably caused by the sinkhole activity directly beside profile 3 , these sections slightly differ in seismic signature. Profile $3 \mathrm{~b}-2$ shows some undulating layer structures of continuous amplitudes to $50 \mathrm{~m}$ depth below reference datum (40$45 \mathrm{~m}$ below the ground surface), which change at the northwest end of the profile to northwest-dipping sequences. In the very southeast part of the profile, a bowl-shaped structure sequence dominates down to $80 \mathrm{~m}$ depth but without any indication of deformation at the surface. Profile 3 mainly shows northwest-dipping structural elements without significant amplitude variations, especially above $100 \mathrm{~m}$ depth. Only small bowl-shaped structures are visible.
The depth section of profile 4 (Fig. 11), which again includes projections of boreholes $\mathrm{BH} 1$ and $\mathrm{BH} 2$ (both in reality located nearly $200 \mathrm{~m}$ northeast of the profile plane), shows mainly slightly northwest-dipping structural signatures. Bowl-shaped structures are restricted to the top $50 \mathrm{~m}$ of the southeast part of the profile, which lies less than $200 \mathrm{~m}$ southwest of where sinkhole activity was reported by El-Isa et al. (1995) and Sawarieh et al. (2000) in the 1990-2000 decade. One sinkhole of $7 \mathrm{~m}$ depth was reported to have formed beside the road prior to 1992. No surface damages were reported for the road track itself, however, and no depressions, cracks, or repairs were visible at the surface during data acquisition. At the northwest end of the section several continuous events of higher amplitudes occur nearly $50 \mathrm{~m}$ below the surface.

Figure 12 shows a 2.5 -D grid of the profiles shown in Figs. 8-11 including the continuation of profile $1 \mathrm{~b}$ along profile 1 . Also integrated are the simplified columns of boreholes $\mathrm{BH} 1$ and $\mathrm{BH} 2$. The reference level at the section top 


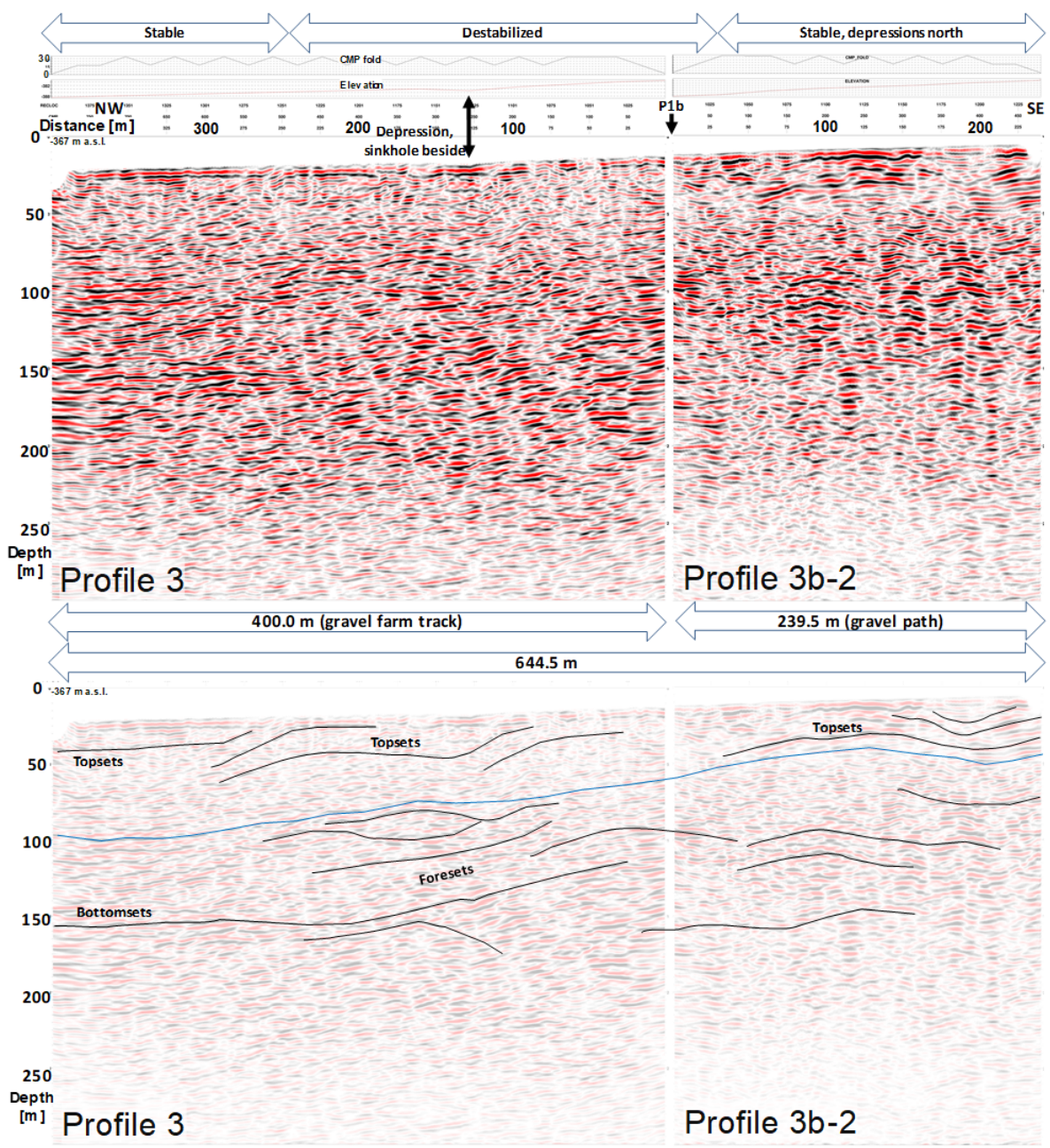

Figure 10. Combined depth sections of profiles 3 and 3b-2 after post stack FD time migration (a) and interpretation of the main structure elements (b). For annotations, see Fig. 8. The interpreted top of the silt and clay layer in BH1 and BH2 is shown by the blue line. The centre part of the profiling track was repeatedly affected by recent sinkhole activity directly beside it to the northeast. For farming access, it was refilled with gravel along more than $250 \mathrm{~m}$ and was subsequently again affected by sinkholes and subsidence. This may cause the weaker reflection signatures in the upper $50 \mathrm{~m}$ when compared to profile 2 (Fig. 8). The main reflection pattern signature is similar to profile 2 and $2 \mathrm{~b}-2$, showing northwest-dipping events. In the southeast of the profile, a v-shaped structure is visible close to surface, filled with nearly horizontal reflection events, which is interpreted as a refilled channel side cut. Due to the wide subsidence area northeast of profile 3 the top of the silt and clay layer (blue line) was continued to the northwest starting from profile $1 \mathrm{~b}$ instead using the projection of BH2.

is $-367 \mathrm{~m}$ a.s.l. The image illustrates that a direct projection of borehole $\mathrm{BH} 2$ to profiles 2 and 4 needs to be carefully handled due to the projection distance of nearly $200 \mathrm{~m}$. Nevertheless, the results of the profiles 2 and 4 both show their main structural dips towards the northwest, which fit the dip tendency of the lithology detected in the boreholes (Fig. 2). Blue markers included along the borehole shafts in Fig. 12 determine the top of the silt and clay layer below the alluvium sequence consisting of gravel and sand. Since this silt and clay layer is the only one detected in the lithology bars of the boreholes that is prone to act as an aquiclude sensitive to subrosion and it also fits the general structural dip, it was obvious that this layer probably extends across the whole area. To interpolate the top of this layer in space (light blue line in Figs. 8-11), it was traced from borehole BH1 along profile $1 \mathrm{~b}$ and profile 1 , from where it was further continued to profiles 2 and $2 b-2$, profiles 3 and $3 b-2$, and profile 4 , with respect to the perpendicular projection of borehole BH2 into the profiles 2 and 4. Subsequently, these layer continuations along the profiles were triangularly interpolated in space to get an impression of the probable layer extent and topography. Regarding the lithology of boreholes $\mathrm{BH} 1$ and $\mathrm{BH} 2$, the constructed horizon represents the estimated base of the upper alluvial gravel and sand unit. The lithology of this upper alluvial unit shows no sequence prone to subrosion, and neither the borehole lithology nor the seismic re- 


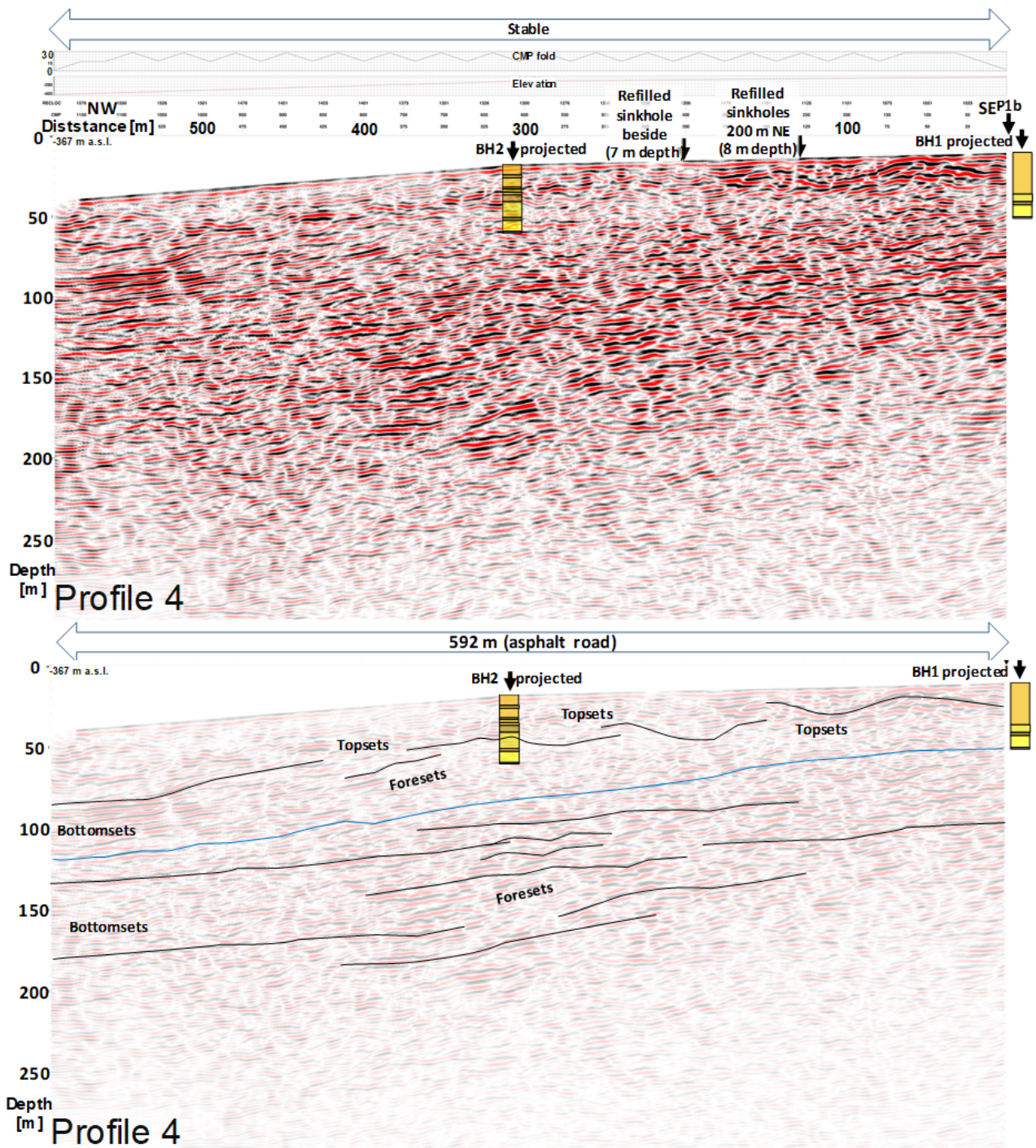

Figure 11. Depth section of profile 4 after post stack FD time migration (a) and interpretation of the main structure elements (b). For annotations, see Fig. 8. Lithology of boreholes $\mathrm{BH} 1$ and $\mathrm{BH} 2$ is projected from $200 \mathrm{~m}$ distance perpendicularly into the profile. In contrast to profile 2, more gently northwest-dipping events are present to $150 \mathrm{~m}$ depth, indicating less transportation energy of the alluvial material or an apparent structure dip. The top of the silt and clay layer in BH1 and BH2 is indicated by the blue line. Bowl-shaped signatures close to the surface in the southeast indicate sinkhole-caused subsidence and/or refilled channel side cuts. Significant reflection amplitudes of a stronger reflector pattern close to the northwest end at nearly $90 \mathrm{~m}$ depth may indicate an evaporite-rich lens included in the alluvium-lacustrine deposits.

flection responses give indications of any included massive salt layers or extended salt lenses. Therefore, subrosion as the origin of the sinkhole process on the exposed alluvial fan is estimated to occur mainly below this constructed horizon within the area of the seismic survey. The deepest part of this constructed horizon reaches $-467 \mathrm{~m}$ a.s.l. towards the northwest, which is $60 \mathrm{~m}$ below the level of the current alluviumto-mudflat transition of $-407 \mathrm{~m}$ a.s.l. at the former shoreline of the Dead Sea in the 1960s (as calculated by Al-Halbouni et al., 2017). It therefore represents a different subrosion level to the present mudflat surface, which indicates that alluvium and silt and clay sequences may lie below the presently exposed mudflat.

\section{Discussion}

The shear wave reflection seismic survey acquired at the Ghor Al-Haditha sinkhole site in 2013 and 2014 was the first comprehensive shallow seismic investigation of the sinkhole phenomenon area since the refraction seismic investigation campaigns carried out by El-Isa et al. (1995) and Sawarieh et 


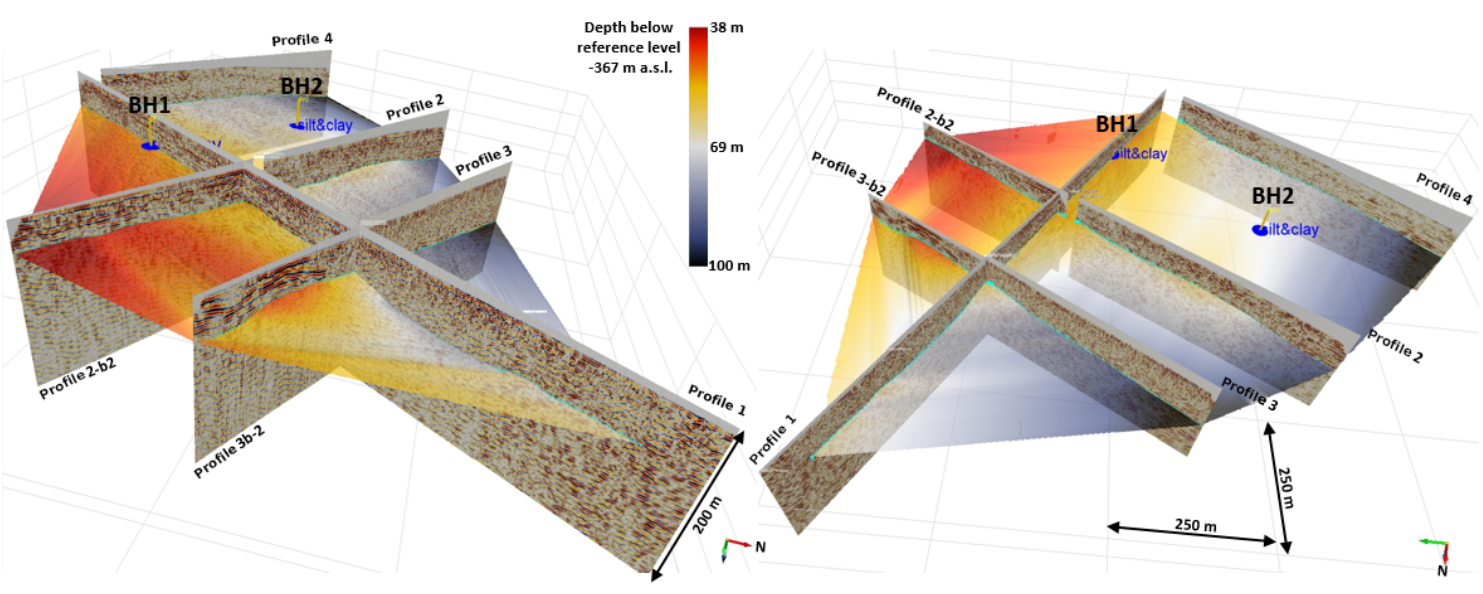

Figure 12. Three-dimensional representation of the 2.5-D profiling grid (cf. sections in Figs. 8-11), restricted to $200 \mathrm{~m}$ depth (no vertical exaggeration). Boreholes $\mathrm{BH} 1$ and $\mathrm{BH} 2$ are included as yellow bars representing the sand and gravel sequence above the detected silt and clay layer, the top of which is marked by a blue disc along each well shaft. Light blue lines along the profiles mark the interpreted continuation of the top of this layer starting from BH1 along profile 1 and subsequently continuing to the crossing profiles. The constructed horizon by triangular interpolation represents the derived top of the silt and clay layer below the reference datum of $-367 \mathrm{~m}$ a.s. 1 . based on the drilling and seismic results. At the deepest parts towards the Dead Sea border the top of this layer reaches nearly $-467 \mathrm{~m}$ a.s. 1 ., which is $60 \mathrm{~m}$ below the level of the current alluvium-mudflat transition of $-407 \mathrm{~m}$ a.s.l. calculated by Al-Halbouni et al. (2017).

al. (2000). The results presented here show the advantageous imaging capabilities of the method regarding high-resolution structural analysis and depth penetration compared to common refraction seismic methods or common P-wave reflection analysis. In this section, we discuss firstly the general outcomes of our application of the S-wave reflection method to an alluvial fan setting and secondly the implications for the nature of processes leading to sinkhole development at the Ghor Al-Haditha site.

\subsection{The application of the shear wave reflection seismic technique to alluvial fan setting}

The S-wave reflection method is especially advantageous in the area close to the Dead Sea border because wave propagation is restricted to the matrix only, and so it is not affected by the pore space content, whether that is air in the shallow unsaturated zone or freshwater or saltwater in the deeper parts below the groundwater level. Therefore the groundwater level itself does not act as a physical interface during wave propagation, as is generally the case for common $\mathrm{P}$ wave methods. In the S-wave profiles acquired in the area, no influence and no response of the groundwater level to the wave propagation was detected. Furthermore, wave propagation velocities of $S$ waves $\left(V_{S}\right)$ are in general significantly smaller than those of $P$ waves $\left(V_{p}\right)$. The $V_{p} / V_{s}$ ratio ranges from nearly 1.7 for an ideal elastic medium (e.g. perfect consolidated rock) to more than 10 (Yilmaz, 2015) for unconsolidated sediments (e.g. Holocene alluvium and soft clays). This leads to a significantly improved resolution when using $S$ waves, depending on the grade of matrix consolidation. In the case of the Ghor Al-Haditha site, this results in a res- olution improvement factor of 8-10 below the groundwater level, when one postulates a similar seismic signal frequency bandwidth for $P$ and $S$ waves.

The success of the application to the alluvial fan setting at Ghor al-Haditha is seen in the well-resolved shallow subsurface structure imaged in the seismic profiles, which show in general mainly northwest-dipping (i.e. lake-ward-dipping) reflectors typical of an alluvial fan sequence prograding into a lacustrine environment. The internal structure is complex and includes typical fan-delta elements such as topsets, foresets, and indications of bottomsets. Especially profile 2 in Fig. 9 shows typical dip structures of a Gilbert-type delta (Gilbert, 1885). Intercalated, more horizontal structures indicate lacustrine deposit layers. The topset structures, the intercalated lacustrine deposit layer and the dip directions fit the lithology of both boreholes $\mathrm{BH} 1$ and $\mathrm{BH} 2$, which show northwest-dipping alluvial sand and gravel above an obviously lacustrine-type deposit denoted as silt and clay (Fig. 2). Below the blue line (Figs. 8-11), stacked foreset structures dominate in profiles $2-4$, connected to bottomset structure indications in the northwest. Due to the absence of borehole information for depths greater than $51 \mathrm{~m}$ below the ground surface, more detailed interpretations remain speculative and require further investigations. With respect to the fluctuations of the Dead Sea level (Bookman (Ken-Tor) et al., 2004) in the past, several levels of included lacustrine-type deposits in the fan architecture are most probable and these may have a complex distribution in three dimensions. For instance, the refill of eroded alluvial channels on the fan surfaces by lacustrine deposits may be a mechanism for the inclusion of soluble fine material in the alluvial fan structure. Furthermore tectonically induced level variations in the whole fan structure, 
caused by the sinistral transform fault movement, cannot be excluded.

Since wave propagation is controlled by the matrix only, the effects of grain size coupling play a key role in the wave propagation of $S$ waves in contrast to $P$ waves. In contrast to P-wave velocity, which usually increases with depth in the case of a fluid-saturated pore space, $\mathrm{S}$-wave velocities often decrease with depth, e.g. if the grain cementation reduces or the pore pressure increases with depth as both factors result in reduced grain contacts. A further reason for velocity function decrease with depth is the influence of a high-velocity layer at the surface, which is the case operating on an asphalt road surface. This effect is visible in the 1-D velocity-depth function in Fig. 8 in the range $0-10 \mathrm{~m}$ below ground surface. Diminished grain coupling can also arise from mechanical damage, e.g. by fracturing, subsidence, and subrosion, which leads to breaks in the direct (geometrical) wave paths. In contrast to $P$ waves, where such breaks may be cut short due to the wave propagation through the pore fluids, decoupling between grains causes additional paths for $S$ waves, leading to enhanced wave energy scattering and an apparent velocity reduction.

In the Ghor Al-Haditha data, enhanced wave energy scattering was observed in areas close to sinkhole activity, leading to transparent zones of weak reflectivity in the seismic sections (e.g. Figs. 8, 10). In the northeast part of profile $1 \mathrm{~b}$ in Fig. 8, the zone of scattered reflections is imaged up to $60 \mathrm{~m}$ depth below the reference level of $-367 \mathrm{~m}$ a.s.l. (i.e. nearly $50 \mathrm{~m}$ below the ground surface), indicating the depth range of the destabilized alluvium. Profile 3 in Fig. 10 shows the continuation of this low-reflectivity zone to $70 \mathrm{~m}$ depth below the reference level (i.e. nearly $50 \mathrm{~m}$ below the ground surface) in the centre of that profile. Beside the transparent zones of strong wave field scattering, buried syncline structures imaged in profiles 2b-2 (Fig. 9), 3b-2 (Fig. 10), and 4 (Fig. 11) are in the depth range of $30-60 \mathrm{~m}$ below ground surface. These synclines probably indicate ancient or recent subsidence by sinkhole activity caused by subrosion below the syncline centres at different horizons. The structures are targets for time-lapse monitoring by shear wave reflection seismics in the upcoming years to evaluate changes in the reflectivity response in detail.

The effect of apparent velocity reduction was also observed, leading partly to irregular interval velocity values of less than zero. Such velocity irregularities can be caused by curved ray paths instead of straight rays which are the base of the CMP concept in reflection seismic. Subrosion-affected zones (e.g. cavities) in the subsurface may cause the shear waves to propagate around affected zones in stiffer material instead of passing them along a straight path. Whereas this velocity problem is of minor importance for the CMP stacking, processing the velocity functions of the individual profiles required careful handling during the time-to-depth conversion, where such zones of irregular velocities would locally compress the depth sections, leading to a distorted structure imaging. Since the discrepancies could not be eliminated due to missing additional velocity information, e.g. by well logging, the final depth conversion was carried out by using a stabilized 1-D velocity function for all profiles (Fig. 8), derived as mean function from profile parts with sufficient reflection responses. Therefore, the resulting depths have to be handled with an estimated error range of up to $20 \%$.

As is well known in hydrocarbon exploration and shallow seismic operations using the seismic refraction, reflection, borehole, and other seismic methods, there are no standalone seismic properties that enable the detection of the lithology or the grain size of a layer. This also holds for other geophysical methods and their combinations. Such conclusions can only be reached if seismic results are calibrated by comprehensive borehole coring in the investigation area. Since the borehole descriptions of $\mathrm{BH} 1$ and $\mathrm{BH} 2$ are based on the analysis of cuttings only, precise lithology depths and the information about grain size derived from the boreholes are in principle poor, and no information is available below the borehole bottoms due to the missing well logging. The alluvial fill rate can be estimated relatively by the borehole lithology profiles and by the seismic structure dips but must be handled with care since geochronological data are limited and the area is close to an active, main sinistral strike-slip transform fault. It is to be expected that, in addition to the lake level variations, tectonic overprints may have changed the whole sedimentation structure over time, even though there was no main fault structure detected in the seismic data.

In summary, the $\mathrm{S}$-wave reflection seismic method achieved advantageous high-resolution imaging results of the alluvial-lacustrine deposit structure at the Ghor AlHaditha sinkhole site; these results are superior to common near-surface seismic investigation methods. The favourable velocity-frequency relationship of the resulting wavelets and the absence of pore fluid effects enabled a metre-scale resolution and a nearly $200 \mathrm{~m}$ penetration depth. Furthermore, and unlike the refraction method, the shear wave reflection method is independent of an obligatory, increasing velocitydepth function. In the case of the sinkhole-affected subsurface structure at Ghor Al-Haditha, where strong vertical and lateral subsurface inhomogeneity occurs, it is not free of shortcomings, and, similar to other geophysical methods, it requires borehole calibration to verify precise depth imaging.

\subsection{Implications of the shear wave reflection seismic results for sinkhole formation}

Combining the reflection amplitude responses and the detected borehole lithologies of BH1 and BH2 (Figs. 8-11) results in no indication of an extended massive salt layer of several metres' thickness in the depth range $35-52 \mathrm{~m}$ below the ground surface, as proposed, e.g., by Taquieddin et al. (2000), Frumkin et al. (2011), Ezersky et al. (2013a, b, c) and Ezersky et al. (2017). If a massive salt layer thicker than 
$2 \mathrm{~m}$ were present in the shallow subsurface down to $200 \mathrm{~m}$ depth, which is our estimated limit of stable imaging, this would result in strong seismic reflection responses in our profiles. A reflection coefficient of nearly 0.5 has to be expected for an alluvium-salt interface if one assumes mass densities for alluvium $\left(\sim 1900 \mathrm{kgm}^{-3}\right)$ and salt $\left(2200 \mathrm{kgm}^{-3}\right)$ and if one assumes the mean shear wave velocity range of 250 $450 \mathrm{~ms}^{-1}$ in the alluvium, as detected during data processing, and at least $1000-1600 \mathrm{~ms}^{-1}$ for a massive salt layer, as reported by Ezersky and Livne (2013) for the boreholes MN$5 \mathrm{E}$ and EB-3E at the western Dead Sea shore. In contrast, the reflection amplitude responses visible below $52 \mathrm{~m}$ depth are similar to the reflection amplitude responses above $52 \mathrm{~m}$ depth, which represent reflection coefficients of nearly 0.1 and less. We also find no indication of anticlinal structures, as one must expect from salt diapirism or salt pillows below $52 \mathrm{~m}$ depth. Finally, there is no structure or amplitude indication of a hard rock basement below the alluvial-lacustrine sequence as imaged in the profiles down to depths of about $200 \mathrm{~m}$. Such low Vs values and reflection coefficients are typical for poorly consolidated alluvial and lacustrine siliciclastic deposits and are consistent with the existing borehole information at Ghor Al-Haditha. Similar low Vs velocities for alluvium and silty clay layers (Vs: $100-600 \mathrm{~m} \mathrm{~s}^{-1}$ ) were reported at the western Dead Sea shore (e.g. Ezersky and Livne, 2013; Gorstein and Ezersky, 2015; Ezersky et al., 2017), as proven by in situ tests in logged boreholes and laboratory tests on related samples.

The previously derived MASW results at the Ghor AlHaditha site (Bodet et al., 2010; Keydar et al., 2011; Ezersky et al., 2013b, 2017) also show Vs of $200-400 \mathrm{~ms}^{-1}$ from the surface to nearly $50 \mathrm{~m}$ depth (magenta profile 3 in Fig. 1) and to nearly $30 \mathrm{~m}$ depth (magenta profile 4 in Fig. 1). Assuming a mean Vs value of $300 \mathrm{~ms}^{-1}$ and taking into account the $4.5 \mathrm{~Hz}$ low-frequency limit of the geophones used for the MASW survey (see the fundamental-mode low-frequency limit in Ezersky et al., 2013b, Fig. 4c), such low Vs values restrict the data-driven maximum Rayleigh wavelength to $62 \mathrm{~m}$ $\left(V_{\mathrm{R}} \sim 0.93 \mathrm{Vs}\right)$. This results in a maximum MASW investigation depth of $31 \mathrm{~m}$ according to, e.g., Park et al. (1999), Rix and Leipski (1991), and Park and Carnevale (2010), in contrast to the rule-of-thumb maximum depth estimation of $60 \mathrm{~m}$ ( 0.5 of the spread length) based on the survey spread length of $120 \mathrm{~m}$. The significance of the high-velocity layer of Vs $>800 \mathrm{~ms}^{-1}$ reported to lie below 35-40 m in MASW profile 4, which is the only reported S-wave evidence of the proposed shallow salt layer at the Ghor Al-Haditha site, must therefore be handled with caution. The strong lateral Vs inhomogeneity reported (Bodet et al., 2010) is also in contrast to the required 1-D layer structure along the spread; such inhomogeneity is well known to cause impaired inversion processing results for the MASW method (Forbriger, 2003).

Due to the significant difference in propagation velocities of $P$ and $S$ waves, the $S$-wave velocity results in this study are not comparable to the $\mathrm{P}$-wave refraction velocity results of the previous studies of El-Isa et al. (1995) and Sawarieh et al. (2000). El-Isa et al. (1995) detected a deepest refractor layer of $\mathrm{Vp} \max 2500-3300 \mathrm{~ms}^{-1}$ at $40-50 \mathrm{~m}$ depth in nearly all of their profiles. In the profiling tracks, which were repeated by Sawarieh et al. (2000) using a similar acquisition configuration, max P-wave refraction velocities $\mathrm{Vp}$ of 2500 and $3130 \mathrm{~ms}^{-1}$ were detected for similar depths, but predominantly the detected velocities were around $2150 \mathrm{~ms}^{-1}$ at nearly $40-50 \mathrm{~m}$ depth. In only one of 24 profiles (no. 5, Fig. 1) of Sawarieh et al. (2000), in the northwest outside the study area of El-Isa et al. (1995) and close to profile 3 of our study, Sawarieh et al. (2000) detected a P-wave velocity of $3948 \mathrm{~ms}^{-1}$ at $70 \mathrm{~m}$ depth, which was interpreted as a salt diapir. Directly beside their profile 5 , in their profile 4 (Fig. 1), Sawarieh et al. (2000) detected a maximum velocity of $2245 \mathrm{~ms}^{-1}$ in $40 \mathrm{~m}$ depth. The area of profile 4 has subsequently been affected since 2000 by massive sinkhole activity and subsidence, which prevented further investigation, whereas the area of profile 5 has remained unaffected until today (see Figs. 1 and 4). For the Ghor Al-Haditha site, these observations of sinkhole development are in direct contradiction to predictions of the salt layer edge model as suggested, e.g., in Ezersky et al. (2017) and as based on the above-mentioned $\mathrm{P}$-wave refraction velocities.

Overall, the P-wave velocities reported for the depth interval of $40-60 \mathrm{~m}$ in past studies are by themselves not indicative of a laterally extensive, thick, massive salt layer at that level. Regarding borehole-defined salt layers on the western shore of the Dead Sea, the overview by Ezersky et al. (2017) notes that P-wave velocities for adjacent alluvial and lacustrine sediments range from 2000 to $2900 \mathrm{~m} \mathrm{~s}^{-1}$, while Pwave velocities for the salt layers themselves range from 2900 to $4500 \mathrm{~m} \mathrm{~s}^{-1}$. The velocities reported for Ghor alHaditha area in the 30-60 m depth level thus overlap with the mid-upper end of the range expected for semi-consolidated, water-saturated, alluvial, or lacustrine deposits and with the lowermost end of the range expected for compacted salt, and they are thus lithologically ambiguous. Moreover, the interpretation of such velocities in terms of a massive salt layer is not supported by borehole data available at Ghor Al-Haditha for the relevant depth interval.

Another hypothesis in discussion (Ezersky et al., 2017) states that the shallow salt layer proposed previously at Ghor Al-Haditha could not be detected in our study because it was already completely dissolved in the period 2006-2013 - i.e. before our survey. This hypothesis would additionally postulate that the lithology description of $\mathrm{BH} 1$ and $\mathrm{BH} 2$ carried out in 1994 may have been flawed because any salt encountered was probably immediately dissolved by the freshwater bore fluid during the drilling process and so did not remain in the analysed cuttings. This latter postulation cannot be assessed since details of the drilling operation and especially the bore fluid are not documented in El-Isa et al. (1995) or elsewhere. Nonetheless, if the proposed $>10 \mathrm{~m}$ thick shallow salt layer (e.g. Taquieddin et al., 2000; Ezersky et al., 
2013a, b, c) was completely subroded in 2006-2013 from the surrounding area of BH1 and BH2 (see Fig. 1b), subsequent extensive sinkhole development as well as more distributed subsidence of several metres have to be expected in this area. This was, however, not the case: the area has been essentially stable since 2006 (see Fig. 4 here and Fig. 4 in Ezersky et al., 2013a).

The most significant horizon in both boreholes for which documentation exists is the silt and clay layer with its top below ground surface at $43 \mathrm{~m}$ in $\mathrm{BH} 1$ and $49 \mathrm{~m}$ in $\mathrm{BH} 2$ because this is the one detected in the boreholes that is most prone to subrosion. The drilling of boreholes $\mathrm{BH} 1$ and $\mathrm{BH} 2$ had been stopped after nearly $2 \mathrm{~m}$ within this layer because it was interpreted as base of the sand and gravel sequence and because it was supposed to act as an aquiclude regarding hydrogeological aspects (El-Isa et al., 1995). Profile 1b (Fig. 8) shows a change in the main reflection pattern at the location of borehole BH1 from nearly the top of this layer (ca. $-420 \mathrm{~m}$ a.s.l., $50 \mathrm{~m}$ b.g.s.) to $110 \mathrm{~m}$ below reference depth (ca. $-470 \mathrm{~m}$ a.s.1., $100 \mathrm{~m}$ below surface). So it is obvious that the thickness of this layer is either more than $2 \mathrm{~m}$, or that this layer is part of a stacked sequence including several silt and clay layers below. Since the depth range of the silt and clay layer was always below the Dead Sea level, the sedimentation of this layer occurred in the lacustrine evaporite-rich environment of the Dead Sea during the last $10 \mathrm{kyr}$ BP (Bookman et al., 2004). By analogy with exposures of lacustrine deposits visible in the sides of 1-8 $\mathrm{m}$ deep freshwater channels that were carved recently into today's mud plain (e.g. Al-Halbouni et al., 2017), there may also be thin evaporite layers $(<1 \mathrm{~m}$ thick) embedded in this silt and clay sequence below the alluvial plain.

The mineralogy of the clay material in the silt and clay layer in $\mathrm{BH} 1$ and $\mathrm{BH} 2$ was not determined by El-Isa et al. (1995). The clay material was only described to be of a green colour; this would be an indication of illite (also called French clay), which is typically described to be of dark olivegrey colour and contains portions of potassium and water. Sawarieh et al. (2000) described several fine-material outcrop sequences in sinkholes at the Ghor Al-Haditha site as marl and clay, both of a greenish-grey colour. This is similar to the composition of Dead Sea mud sampled at the eastern shoreline by Khlaifat et al. (2010), which typically consists of $>40 \%$ fine carbonates (aragonite, calcite, $\mathrm{CO}_{2}$ ), up to $20 \%$ clay, $20 \%$ quartz, and, additionally, halite, water, and further minerals in fractions. The absence of another source for such fine-material layers forces the assumption that the majority of silty-clayey fine-material layers included in the alluvial fan are Dead Sea mud, probably in different mineral compositions depending on the environmental conditions during sedimentation. Due to the high content of included marl and evaporites, all these layers are prone to dissolution and subrosion instead of acting as an aquiclude consisting of pure clay. Such dissolution and erosion processes can be observed today in the mud plain all around the Dead Sea, where fresh- water channels from the highlands or springs meet the Dead Sea shoreline, forming erosion channels in the mud plain, both on the surface and in the subsurface (Al-Halbouni et al., 2017).

This solution process may in places be amplified by a physical effect well known for the so-called "quick clays" in Nordic countries (Geertsema, 2013). Quick clays are originally deposited in a salt-rich marine environment in the Northern Hemisphere during glaciation where they formed an electrostatically bonded double-layer structure including a cation (e.g. sodium) between two clay particles. When these clays become no longer subjected to saltwater conditions (due to isostatic uplifts in Nordic countries and due to a decrease in the Dead Sea level in our study area) and freshwater infiltrates these clays, washing away the cations, the clay particles do not remain in a stable bonded structure and change to a liquid behaviour. Such a process was previously proposed by Arkin and Gilat (2000) for the Dead Sea sinkholes, although the relatively low clay content of up to $20 \%$ detected in the fine-material sediments around the Dead Sea (e.g. Khlaifat et al., 2010) indicates that such a process accounts for only a minor portion of the subrosion process.

In line with Krawczyk et al. (2015), we therefore propose a new, combined process model based on both chemical and mechanical erosion: the fine-material stacks of marl, silt, and clay within the alluvial fan change progressively from solid to liquid behaviour in the contact area of the freshwater inflow due to (chemical) leaching of the carbonate and evaporite particles first. Secondly, the clay particles are mechanically destabilized and eroded along the path of the subsurface water flow after the loss of the (physical) stabilizing cations of the double-layer structures. This process results in rapidly growing subsurface channels and cavities in very short times, continuously amplified by the increasing (mechanical) kinetic energy of the water stream as documented for a spring by Al-Halbouni et al. (2017). Thirdly, even alluvial material at the subrosion interface gets washed out. The cavities extend horizontally and grow upward until the gravitation force of overlying alluvial stratum exceeds its bonding forces. This initializes a sudden sinkhole. The process is controlled by the long-term, seasonal, and ephemeral movement of the saltwater-freshwater interface (Salameh and ElNaser, 2000; Alrshdan, 2012), the volume of the fresh water flow and its velocity, and the volume of buried soluble and/or mechanically erodible material and its mechanical properties within the alluvial fan.

\section{Conclusions}

The shear wave reflection seismic study at the Ghor AlHaditha sinkhole investigation site was the first experiment where this geophysical investigation method was applied in the environment of the Dead Sea. The achieved depth sections demonstrate that the technique can be applied in allu- 
vial fan deposits in arid areas, which opens new feasibilities for shallow subsurface exploration of the Dead Sea sinkhole problem at a high resolution.

In general, the profiling results show a complex contact area between the high-energy prograding alluvial fans of the Wadi Ibn Hammad and Wadi Mutayl and the low-energy lacustrine sedimentation environment of the Dead Sea. None of the available outcrop and borehole lithological data show evidence of any thick massive salt layers in the shallow subsurface of the survey area down to $51 \mathrm{~m}$ depth below ground surface. This range can be extended with the new seismic data, which do not give any indication of a thick ( $>2 \mathrm{~m}$ ) compacted salt layer down to $200 \mathrm{~m}$ depth below the ground surface. Furthermore, there are no structural indications of diapiric uplifts in the survey area. Also, since the hard rock basement was not detected down to that depth, the thickness of the Pliocene-Holocene alluvial-lacustrine sequence is $>200 \mathrm{~m}$.

Based on the shear wave reflection seismic results and supported by the drilled stratigraphy, our new model for the sinkhole process at the Ghor Al-Haditha sinkhole site suggests that the dissolution of small, distributed inclusions of marl, silt, clay, and evaporites within the alluvial fan is enhanced by freshwater intrusions from the eastern wadis. Furthermore, we propose that such chemical erosion in the subsurface exists in a feedback with mechanical erosion of weak material, especially silt and clay, and with higher flow velocities of poorly consolidated alluvial material also. The process is not restricted to the depth of the silt and clay layer detected in the boreholes $\mathrm{BH} 1$ and $\mathrm{BH} 2$ and outlined in the area; it can also affect shallower or deeper layer-like inclusions of weak, soluble, non-massive lacustrine material. Consequently, geophysics-based mapping of areas prone to sinkhole hazard at the Dead Sea should consider different lithological controls on the location of sinkhole development.

Areas of future sinkhole development may be indicated by time-lapse monitoring using shear wave reflection seismic methods. The observation of time-dependent structure changes in the subsurface and changes in irregular velocity zones caused by disaggregation or cavity formation is recommended as a tool to indicate ongoing sinkhole development. This aspect will be the focus of investigation in upcoming experiments.

Data availability. Data are the property of LIAG and will be used for further investigations and publications by the authors. Parts of the data set are available by request to the first author.

Author contributions. All authors contributed to the scientific content, interpretations, message of the paper, and the discussions. Except for M.Y. Atallah, who mainly supported the interpretation part, all authors participated in seismic data acquisition from the beginning.
Competing interests. The authors declare that they have no conflict of interests.

Special issue statement. This article is part of the special issue "Environmental changes and hazards in the Dead Sea region (NHESS/ACP/HESS/SE inter-journal SI)". It is not associated with conference.

Acknowledgements. The investigation was operated in the framework of the DEad SEa Research Venue (DESERVE), a virtual research institute of the Helmholtz Association, designed as a cross-disciplinary and cooperative international project of the Helmholtz Centres KIT, GFZ, UFZ, and their partners. The authors gratefully acknowledge the DESERVE virtual institute for continuous financial support of the investigations. The geology group of the Jordan Ministry of Energy and Mineral Resources (MEMR) - formerly Natural Resource Authority (NRA) of Jordan - provided professional logistic support during equipment shipping and data acquisition, as well as by their excellent field camp infrastructure at Ghor Al-Haditha, enabling fast access to the investigation area. Special thanks to Alexandra Carina Gassner and Khalil Abu Ayyash for the support during the project. We are grateful to Damien Closson for providing us with a high-quality copy of the El-Isa et al. (1995) report. We thank an anonymous reviewer and Pauline Kruiver (Deltares) for critical review and helpful suggestions and comments to improve the paper.

Edited by: Ulrike Werban

Reviewed by: Pauline Kruiver and one anonymous referee

\section{References}

Abelson, M., Yechieli, Y., Crouvi, O., Baer, G., Wachs, D., Bein, A., and Shtivelman, V.: Evolution of the Dead Sea sinkholes, in: New frontiers in Dead Sea paleoenvironmental research, edited by: Enzel, Y., Agnon, A., and Stein, M., Geological Society America Special paper, 401, 241-253, https://doi.org/10.1130/2006.2401(16), 2006.

Abelson, M., Gabay, R., Shalev, E., and Yechieli, Y.: Sinkhole hazard around the evaporation ponds Dead Sea southern basin, Geological Survey of Israel, Report GSI/27/2009, 2009.

Abelson, M., Yechieli, Y., Baer, G., Lapid, G., Behar, N., Calvo, R., and Rosensaft, M.: Natural versus human control on subsurface salt dissolution and development of thousands of sinkholes along the Dead Sea coast, J. Geophys. Res.-Earth, 122, https://doi.org/10.1002/2017JF004219, 2017.

Abou Karaki, N, Fiaschi, S, and Closson, D.: Sustainable development and anthropogenic induced geomorphic hazards in subsiding areas, Earth Surf. Proc. Land., 41, 2282-2295, https://doi.org/10.1002/esp.4047, 2016.

Abueladas, A. and Al-Zoubi, A.: The application of a combined geophysical survey (GPR and seismic refraction) for mapping sinkholes in Ghor Al-Haditha Area, Jordan, Fall Meeting Supplement, EOS Transactions, American Geophysical Union, 85, p. 47, Abstract GP11A-0825, 2004. 
Al-Halbouni, D., Holohan, E. P., Saberia, L., Alrshdan, H., Sawarieh, A., Closson, D., Waltera, T. R., and Dahm, T.: Sinkholes, subsidence and subrosion on the eastern shore of the Dead Sea as revealed by a close-range photogrammetric survey, Geomorphology, 285, 305-324, https://doi.org/10.1016/j.geomorph.2017.02.006, 2017.

Alrshdan, H.: Geophysical Investigations of Ghor Haditha Sinkholes, Jordan, EAGE Workshop on Dead Sea Sinkholes - Causes, Effects and Solutions, Session 1: Geology, Hydrogeology \& Hydrochemistry of Sinkholes, https://doi.org/10.3997/2214-4609.20143060, 2012.

Aki, K. and Richards, P. G.: Quantitative seismology, W.H. Freeman and Company, San Francisco, 1980.

Arkin, Y. and Gilat, A.: Dead Sea sinkholes - an ever-developing hazard, Environ. Geol., 39, 711-722, 2000.

Barjous, M., Sweidan, G., and AL-Atteyat, N.: Geophysical and geological investigation of sinkholes in Ghor Al-Haditha area, Sinkhole project of Ghor Al-Haditha area (phase 4), Natural Resources Authority, Internal Report, Amman, 2004.

Batayneh, A., Abueladas, A., and Moumani, K.: Use of groundpenetrating radar for assessment of potential sinkhole conditions: an example from Ghor Al-Haditha area, Jordan, Environ. Geol., 41, 977-983, 2002.

Bodet, L., Galibert, P. Y., Dhemaied, A., Camerlynck, C., and AlZoubi, A.: Surface-wave profiling for sinkhole hazard assessment along the eastern Dead Sea shoreline (Ghor Al-Haditha, Jordan), 72nd EAGE Conference \& Exhibition incorporating SPE EUROPEC 2010, Barcelona, Spain, 14-17 June 2010 (M027), 2010.

Bookman (Ken-Tor), R., Enzel, Y., Agnon, A., and Stein, M.: Late Holocene lake levels of the Dead Sea, Geol. Soc. Am. B., 116, 555-571, 2004

Camerlynck, C. M., Abueladas, A., Al-Ruzouq, R., Al-Zoubi, A., Boucher, M., Bodet, L., Dhemaied, A., and Galibert, P.Y .: Geophysical assessment of sinkhole hazard evaluation at Ghor Haditha (Dead sea, Jordan). Expanded Abstract DS07, EAGE Workshop on Dead Sea Sinkholes - Causes, Effects \& Solutions, 23-26 September 2012, Amman, Jordan, 2012.

Closson, D.: Structural control of sinkholes and subsidence hazards along the Jordanian Dead Sea coast, Environ. Geol., 47, 290$301,2005$.

Closson, D. and Abu Karaki, N.: Salt karst and tectonics: sinkholes development along tension cracks between parallel strike-sleep faults, Dead Sea, Jordan, Earth Surf. Proc. Land., 34, 1408-1421, https://doi.org/10.1002/esp.1829, 2009.

Crawford, J. M., Doty, W., and Lee, M. R.: Continuous signal seismograph, Geophysics, 25, 95-105, 1960.

Dhemaied, A.: Tomographie seismique d'une zone de subsidence (Sinkhole zone, Ghor Al-Haditha, Jordanie), MSc Report (unpublished), Paris University, Paris, France, 2007.

Diabat, A. A.: Sinkholes related to Tectonic Factor at Ghor Al Haditha Area, Dead Sea, Jordan, Hydrogeologie und Umwelt, 33, $1-17,2005$.

Dix, C. H.: Seismic velocities from surface measurements, Geophysics, 20, 68-86, 1955.

El-Isa, Z. H., Rimawi, O., Jarrar, G., Abu-Karaki, N., Taqieddin, S. A., Atallah, M., Seif El-Din, N., and Al-Saed, A.: Assessment of the hazard of subsidence and sinkholes in Ghor Al-Haditha area. Report submitted to Jordan Valley Authority, University of
Jordan, Amman, University of Jordan, Center For Consultation, Technical Services and Studies, Amman, 141 pp., 1995.

Ezersky, M.: The seismic velocities of Dead Sea salt applied to the sinkhole problem, J. Appl. Geophys., 58, 45-58, 2006.

Ezersky, M. and Frumkin, A.: Fault-Dissolution front relations and the Dead Sea sinkhole problem, Geomorphology, 201, 35-44, 2013.

Ezersky, M. and Livne, E.: Geotechnical and geophysical properties of soils in the Dead Sea sinkhole problem. Near Surface Geoscience, Bochum, Germany, Expanded Abstract Mo P, 13, 5 pp., 2013.

Ezersky, M., Legchenko, A., Camerlynck, C., Al-Zoubi, A., Eppelbaum, L., Keydar, S., Baucher, M., and Chalikakis, K.: The Dead Sea sinkhole hazard - new findings based on a multidisciplinary geophysical study, Z. Geomorphol., 54, 69-90, https://doi.org/10.1127/0372-8854/2010/0054S2-0005, 2010.

Ezersky, M. G., Eppelbaum, L. V., Al-Zoubi, A., Keydar, S., Abueladas, A.-R., Akkawi, E., and Medvedev, B.: Geophysical prediction and following development sinkholes in two Dead Sea areas, Israel and Jordan, J. Environ. Earth Sci., 70, 1463-1478, https://doi.org/10.1007/s12665-013-2233-2, 2013a.

Ezersky, M., Bodet, L., Akkawi, E., Al-Zoubi, A., Camerlynck, C., Dhemaied, A., and Galibert, P.-Y.: Seismic Surface-wave prospecting methods for sinkhole hazard assessment along the Dead Sea shoreline, J. Environ. Eng. Geophys., 18, 233-253, https://doi.org/10.2113/JEEG18.4.233, 2013b.

Ezersky, M., Keydar, S., Al-Zoubi, A., and Eppelbaum, E.: Sinkhole hazard assessment of the Dead Sea area in Israel and Jordan: A multidisciplinary study, Final Technical Report Project M27-050, US Agency for International Development, Bureau of Global programs, Field Support and research, Center of Economic Growth and Agricultural Development, Washington D.C., 142 pp., 2013c.

Ezersky, M. G., Legchenko, A., Eppelbaum, L., and Al-Zoubi, A.: Overview of the geophysical studies in the Dead Sea costal area related to evaporate karst and recent sinkhole development, Int. J. Speleol., 46, 227-302, 2017.

Fiaschi, S., Closson, D., Abou Karaki, N., Pasquali, P., Riccardi, P., and Floris, M.: The complex karst dynamics of the Lisan Peninsula revealed by 25 years of DInSAR observations, Dead Sea, Jordan, ISPRS J. Photogramm., 130, 358-369, https://doi.org/10.1016/j.isprsjprs.2017.06.008, 2017.

Forbriger, T.: Inversion of shallow-seismic wavefields Part II: Inferring subsurface properties from wavefield transforms, Geophys. J. Int., 153, 735-752, 2003.

Frumkin, A., Ezersky, M., Al-Zoubi, A., Akkawi, E., and Abueladas, A.-R.: The Dead Sea hazard: geophysical assessment of salt dissolution and collapse, Geomorphology, 134, 102-117, https://doi.org/10.1016/j.geomorph.2011.04.023, 2011.

Frydman, S., Charrash, J., and Goretsky, I.: Geotechnoical properties of evaporate soils of the Dead sea area, Eng. Geol., 101, 236-244, 2008.

Geertsema M.: Quick Clay, in: Encyclopedia of Natural Hazards, edited by: Bobrowsky, P. T., Encyclopedia of Earth Sciences Series, Springer, Dordrecht, 2013.

Gilbert, G. K.: The topographic features of lake shores, US Geol. Surv. Ann. Rep., 5, 69-123, 1885.

Gorstein, M. and Ezersky, M.: Combination of HVSR and MASW methods to obtain shear wave velocity model of subsurface in Is- 
rael, IJGE, 1, 20-41, https://doi.org/10.15273/ijge.2015.01.004, 2015.

Inazaki, T.: High resolution reflection surveying at paved areas using S-wave type land streamer, Explor. Geophys., 35, 1-6, 2004.

Keydar, S., Bodet, L., Camerlynck, C., Dhemaied, A., Galibert, P.Y., Ezersky, M. G., Dror, O., Akkawi, E., and Al-Zoubi, A.: A new approach for shallow subsurface imaging and its application to the Dead Sea sinkhole problem, 73th EAGE Conference and Technical Exhibition, Vienna, Austria, Expanded Abstracts A401, 4 pp., 2011.

Khalil, B. M.: The geology of the Ar-Rabba area, map sheet No. 3152 IV. NRA, Mapping Project Bull., 22, 106 pp., 1992.

Khlaifat, A., Al-Khashman, O., and Qutob, H.: Physical and chemical characterization of Dead Sea mud, Mater. Charact., 61, 564568,2010

Krawczyk, C. M., Polom, U., Trabs, S., and Dahm, T.: Sinkholes in the city of Hamburg - New urban shear wave reflection seismic system enables high-resolution imaging of subrosion structures, J. Appl. Geophys., 78, 133-143, https://doi.org/10.1016/j.jappgeo.2011.02.003, 2012.

Krawczyk, C. M., Polom, U., Alrshdan, H., Al-Halbouni, D., Sawarieh, A., and Dahm, T.: New process model for the Dead Sea sinkholes at Ghor Al Haditha, Jordan, derived from shearwave reflection seismics, Geophysical Research Abstracts, 17, EGU2015-5761, 2015.

Legchenko, A., Ezersky, M., Boucher, M., Camerlynck, C., AlZoubi, A., and Chalikakis, K.: Estimating sinkhole hazard in the Dead Sea costal area using P-wave velocities and magnetic resonance soundings, Near Surface 2008, Krakow, Poland, Expanded Abstract P18, 5 pp., 2008.

Park, C., Miller, R., and Xia, J.: Multichannel analysis of surface waves, Geophysics, 64, 800-808, 1999.

Park, C. B. and Carnevale, M.: Optimum MASW survey - revisit after a decade of use: Geo-Institute Ann. Mtng (GeoFlorida 2010), 20-24 February 2010, West Palm Beach, FL, 2010.

Polom, U.: Elimination of source-generated noise from correlated vibroseis data (the "ghost-sweep" problem), Geophysical Prospecting, 45, 571-591, 1997.

Polom, U., Druivenga, G., Grossmann, E., Grüneberg, S., and Rode, W.: Transportabler Scherwellenvibrator, Patent application DE 10327757 A1, Deutsches Patent- und Markenamt, 2011 (in German).

Polom, U., Bagge, M., Wadas, S., Winsemann, J., Brandes, C., Binot, F., and Krawczyk, C. M.: Surveying near-surface depotcentres by means of shear wave seismic, First Break, 31, 67-79, 2013.

Polom, U., Mueller, C., Nicol, A., Villamor, P., Langridge, R. M., and Begg, J: Finding the concealed section of the Whakatane Fault in the Whakatane Township with a shear wave landstreamer system: A seismic surveying report. GNS Science Open File Report 2016/41, 41 pp., GNS Science, New Zealand, 2016.

Pugin, A. J. M., Larson, T. H., and Sargent, S. L.: Near-surface mapping using SH-wave and P-wave seismic land-streamer data acquisition in Illinois, U.S. The Leading Edge, 23, 677-682, 2004.

Pugin, A. J. M., Hunter, A. J., Motazedian, D., Brooks, G. R., and Kasgin, K. B.: An application of shear wave reflection landstreamer technology to soil response evaluation of earthquake shaking in an urban area, Ottawa, Ontario, Symposium on the Application of Geophysics to Engineering and Environmen- tal Problems (SAGEEP), Environmental and Engineering Geophysics society Annual Meeting, Denver, Colorado, USA, 1-5 April 2007.

Pugin, A. J. M., Pullan, S. E., Hunter, J. A., and Oldenborger, G. A.: Hydrological prospecting using P- and S-wave landstreamer seismic reflection methods, Near Surface Geophysics, 7, 315327, 2009.

Pugin, A. J. M., Pullan, S. E., and Hunter, A. J.: Shear-wave highresolution reflection in Ottawa and Quebec City, Canada, The Leading Edge, 250-255, 2013.

Rix, G. J. and Leipski, E. A.: Accuracy and resolution of surface wave inversion, in: Recent Advances in Instrumentation, edited by: Bhatia, S. K. and Blaney, G. W., Data Acquisition and Testing in Soil Dynamics: Am. Soc. Civil Eng., 17-32, 1991.

Salameh, E. and El-Naser, H.: The interface configuration of the fresh-/Dead Sea water - Theory and measurements, Acta Hydroch. Hydrob., 28, 323-328, 2000.

Sawarieh, A. and Alrshdan, H.: The relation of sinkholes development in Ghor Al-Haditha area with the Dead Sea level fluctuations, Natural Resources Authority (Internal report), Amman, 2011.

Sawarieh, A., Abueladas, A. A., Al Bashish, M., and Al Seba'i, E.: Sinkholes Phenomena at Ghor Al-Haditha area: Sinkholes Project (Phase-2), Natural Resources Authority, Internal Report No. 12, Amman, 2000.

Shalev, E., Lyakhovsky, V., and Yechieli, Y.: Salt dissolution and sinkhole formation along the Dead Sea shore, J. Geophys. Res., 111, B03102, https://doi.org/10.1029/2005JB004038, 2006.

Taqieddin, S., Abderahman, N., and Atallah, M.: Sinkhole hazard along the eastern Dead Sea shoreline area, Jordan: a geological and geotechnical consideration, Environ. Geol., 39, 1237-1253, 2000.

Wachs, D., Yechieli, Y., Shtivelman, V.,Itamar, A., Bear, G., Goldman, M., Raz, E., Riebekov, M., and Shatner, U.: Formation of sinkholes along the shore of the Dead Sea - summary of finding from the first stage of research, Geological Survey Report GSI/41/2000 (in Hebrew), 49 pp., 2000.

Yechieli, Y., Wachs, D, Abelson, M., Crouvi, O., Shtivelman, V., Raz, E., and Baer, G.: Formation of Sinkholes along the Shore of the Dead S - Summary of the first Stage of Investigation Geological Survey of Israel, Curr. Res., 13, 1-6, 2002.

Yechieli, Y., Abelson, M., Bein, M., Crouvi, O., and Shtivelman, V.: Sinkhole "swarms" along the Dead Sea coast: reflection of disturbance of lake and adjacent groundwater systems, Geol. Soc. Am B., 118, 1075-1087, https://doi.org/10.1130/B25880.1, 2006.

Yilmaz, Ö.: Seismic Data Analysis, Society of Exploration Geophysicists, Tulsa, 2001.

Yilmaz, Ö.: Engineering seismology with applications to geotechnical engineering, in: Investigation in Geophysics Series No. 17, edited by: Miller, R. D., Society of Exploration Geophysicists, Tulsa, 2015. 